
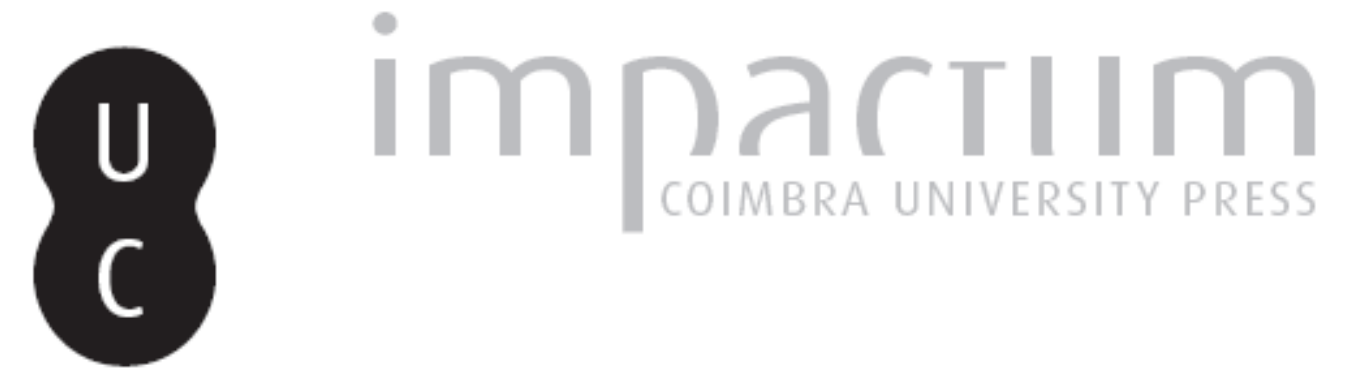

Instituições de piedade e beneficência do distrito de Coimbra na década de $\mathbf{1 8 7 0}$

Autor(es): $\quad$ Lopes, Maria Antónia

Publicado por: Centro de História da Sociedade e da Cultura

URL persistente:

URI:http://hdl.handle.net/10316.2/39487

DOI:

DOI:http://dx.doi.org/10.14195/1645-2259_11_13

Accessed : $\quad$ 26-Apr-2023 00:48:26

A navegação consulta e descarregamento dos títulos inseridos nas Bibliotecas Digitais UC Digitalis, UC Pombalina e UC Impactum, pressupõem a aceitação plena e sem reservas dos Termos e Condições de Uso destas Bibliotecas Digitais, disponíveis em https://digitalis.uc.pt/pt-pt/termos.

Conforme exposto nos referidos Termos e Condições de Uso, o descarregamento de títulos de acesso restrito requer uma licença válida de autorização devendo o utilizador aceder ao(s) documento(s) a partir de um endereço de IP da instituição detentora da supramencionada licença.

Ao utilizador é apenas permitido o descarregamento para uso pessoal, pelo que o emprego do(s) título(s) descarregado(s) para outro fim, designadamente comercial, carece de autorização do respetivo autor ou editor da obra.

Na medida em que todas as obras da UC Digitalis se encontram protegidas pelo Código do Direito de Autor e Direitos Conexos e demais legislação aplicável, toda a cópia, parcial ou total, deste documento, nos casos em que é legalmente admitida, deverá conter ou fazer-se acompanhar por este aviso.

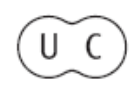




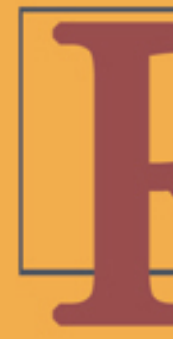

\section{evista de História} da Sociedade e da Cultura

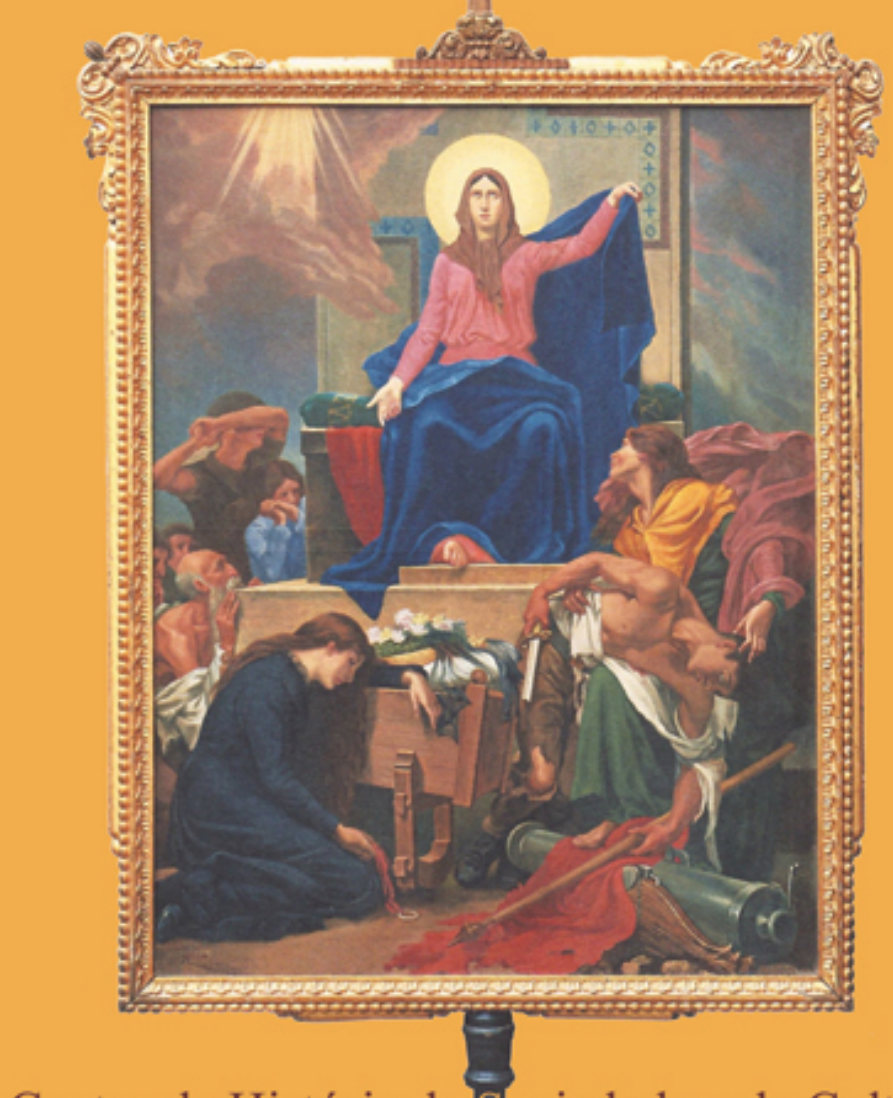

Centro de História da Sociedade e da Cultura Universidade de Coimbra 


\title{
Instituições de piedade e beneficência do distrito de Coimbra na década de 1870*
}

\author{
Maria Antónia Lopes \\ Faculdade de Letras \\ Centro de História da Sociedade e da Cultura da Universidade de Coimbra \\ mafilopes@netvisao.pt \\ Texto recebido em/ Text submitted on: 28/02/2011 \\ Texto aprovado em/ Text approved on: 07/07/2011
}

\section{Resumo/Abstract:}

A portaria de 12 de Junho de 1876 ordenou a execução de um inquérito às instituições de piedade e de beneficência portuguesas, o que se praticou no distrito de Coimbra ao longo dos anos 1876 a 1878. Exploram-se neste artigo os cadastros resultantes do cumprimento da portaria. Com a sua análise, é possível quantificar com exactidão esse universo institucional, traçar a sua distribuição no espaço e estabelecer a sua dimensão humana e o que ela representava no conjunto da população. É possível também determinar (com rigor nos institutos assistenciais e com grande aproximação nos de piedade) a sua situação patrimonial e financeira, aquilatar do cumprimento da lei de desamortização e avaliar o seu papel no socorro às populações.

The governmental decree of $12^{\text {th }}$ June 1876 ordered an inquiry to the piety and charity Portuguese institutions, which took place in the district of Coimbra during the years of 1876 to 1878 . This paper searches into the cadastre that outcome from the application of the decree. By its examination is possible to quantify precisely this institutional universe, to draw its spatial display and establish its human dimension and what it represents within the whole population. It is also possible to ascertain (rigorously concerning the assistance institutions and approximately concerning the piety institutions) its patrimonial and financial state, to verify the application of the disentail law and to evaluate its role in the assistance to the populations.

Palavras chave/Keywords:

Distrito de Coimbra, século XIX; Misericórdias; Hospitais; Asilos; Confrarias.

District of Coimbra; XIX century; Charitable institutions; Hospitals; Asylums; Brotherhoods.

* Agradeço aos Professores João Roque e Rui Cascão a leitura crítica que fizeram deste texto. 


\section{Considerações prévias}

A Historia da beneficencia publica em Portugal de Victor Ribeiro', o capítulo "Assistência" de Ângelo Ribeiro e Damião Peres² e a entrada "Assistência na Idade Contemporânea" de Fernando Jasmins Pereira ${ }^{3}$ elencam um grande número de instituições de beneficência portuguesas ao tempo do Liberalismo monárquico. São importantes pontos de partida, mas insuficientes e com equívocos, como não podia deixar de ser à data em que foram produzidos e face à carência de estudos locais. Contudo, salvo honrosas e pontuais excepções, o desinteresse historiográfico pelo tema persistiu. Mais acentuado, ainda, no que respeita ao universo das confrarias.

As sínteses publicadas na História de Portugal dirigida por José Mattoso ${ }^{4}$, na Nova História de Portugal coordenada por Joel Serrão e Oliveira Marques $^{5}$ e no Dicionário de História Religiosa de Portugal dirigido por Carlos Moreira de Azevedo ${ }^{6}$ definiram as políticas sociais de Oitocentos e tipificaram as instituições assistenciais e as confraternais ${ }^{7}$. Mas são

1 Coimbra: Imprensa da Universidade, 1907.

2 In Peres, Damião (dir.) - História de Portugal, vol. VII [1816-1918]. Barcelos: Portucalense Editora, 1935, p. 785-792.

3 In Andrade, A. A. Banha de (dir.) - Dicionário de História da Igreja em Portugal. Lisboa: vol. I., Resistência, 1980, p. 686-717.

4 Lopes, Maria Antónia - Os pobres e a assistência pública in Torgal, Luís Reis e RoQue, João Lourenço (coord.) - O Liberalismo [1820-1890]. Lisboa: Círculo de Leitores, 1993, p. 500-515; CASCÃo, Rui - Vida quotidiana e sociabilidade in IDEM, ibidem, p. 517-541. Temática ausente no volume VI [1890-1926].

5 Braga, Paulo Drumond - Igreja, igrejas e culto in Marques, A. H. de Oliveira (coord.) - Portugal e a instauração do Liberalismo [1815-1851]. Lisboa: Presença, 2002, p. 307-334; Dias, Geraldo Coelho - Igreja, igrejas e culto in Sousa, Fernando de e Marques, A. H. de Oliveira (coord.) - Portugal e a Regeneração [1851-1900]. Lisboa: Presença, 2004, p. 269-302. MARQues, A. H. de Oliveira e Rodrigues, Luís Nuno - A sociedade e as instituições sociais in Marques, A. H. de Oliveira (coord.) - Portugal da Monarquia para a República [1900-1930]. Lisboa: Presença, 1991, p. 187-239.

${ }^{6}$ SÁ, Isabel dos Guimarães - Assistência II. Época Moderna e Contemporânea in Azevedo, Carlos Moreira de (dir.) - Dicionário de História Religiosa de Portugal. Lisboa: vol. A-C, Círculo de Leitores, 2000, p.140-149; TeIXEIRA, Maria Elvira - Assistência. Do fim da Monarquia ao Estado Novo in IDEM, ibidem, p. 149-152; Penteado, Pedro - Confrarias in IDEM, ibidem, p. 459-470; ARAÚJo, António de Sousa - Ordens Terceiras in IDEM, ibidem, vol. J-P, 2001, p. 348-354; PenteAdo, Pedro - Misericórdias nos séculos XIX e XX in IDEM, ibidem, vol. P-V/Apêndices, 2001, p. 457-459.

7 Vejam-se um elenco de títulos e um balanço historiográfico, ambos de finais da década de 1990: Gomes, Pinharanda - Confrarias, Misericórdias, Ordens Terceiras, Obras Pias e 
textos de valor muito desigual (reproduzindo alguns deles erros factuais e interpretativos) que não traçaram, nem podiam traçar, a distribuição no espaço desse universo institucional, a sua situação patrimonial e financeira, a sua dimensão demográfica enquanto associações, a sua real importância no socorro às populações - aspectos que aqui se pretendem estudar. Vários trabalhos posteriores, também com grandes disparidades ao nível da elaboração, trouxeram informações rigorosas e importantes sobre o funcionamento de instituições beneficentes e, em muito menor grau, sobre irmandades ou confrarias ${ }^{8}$.

outras associações de fiéis em Portugal nos séculos XIX e XX: bibliografia institucional (contributo). Lusitania Sacra. 8/9 (1996/1997) 611-648; LoPes, Maria Antónia (c/ RoQue, João Lourenço) - Pobreza, asistencia y política social en Portugal en los siglos XIX e XX. Perspectivas historiográficas in Esteban de Vega, Mariano (ed.) - Pobreza, beneficencia y política social. Madrid: Marcial Pons, 1997, p. 211-240 (republicado em português in A Cidade e o Campo. Colectânea de Estudos. Coimbra, CHSC, 2000, p. 63-83).

8 Indico sem pretender ser exaustiva: Lopes, Maria Antónia - Pobreza, assistência e controlo social em Coimbra (1750-1850). Viseu: Palimage, 2000. BarreIrA, Aníbal José de Barros - A assistência hospitalar no Porto: 1750-1850. Porto: Tese de Doutoramento apresentada à Universidade do Porto, 2002. Lopes, Maria Antónia - As Misericórdias: de D. José ao final do século XX in Paiva, José Pedro (coord.) - Portugaliae Monumenta Misericordiarum 1. Fazer a história das Misericórdias. Lisboa: União das Misericórdias Portuguesas, 2002, p. 79-117. OliveIra, Carla - A Ordem Terceira de São Francisco na cidade de Guimarães (1850-1910). Braga: Tese de Mestrado apresentada à Universidade do Minho, 2003. Lopes, Maria Antónia - Provedores e escrivães da Misericórdia de Coimbra de 1700 a 1910. Elites e fontes de poder. Revista Portuguesa de História, 36-2 (2003/04) 203-274. FArIA, Ana Mouta - Sinais do Espírito Santo no limiar do século XIX: estruturas e manifestações culturais in SERRÃo, José Vicente e ABreu, Laurinda (coord.) - Em nome do Espírito Santo. História de um culto. Lisboa: Instituto dos Arquivos Nacionais/Torre do Tombo, 2004, p. 101-115. FonTe, Teodoro Afonso da - No limiar da honra e da pobreza. A infância desvalida e abandonada no Alto Minho (1698-1924). Braga: Tese de Doutoramento apresentada à Universidade do Minho, 2004. Araúso, Maria Marta Lobo de - A Confraria de Nossa Senhora do Porto de Ave. Um itinerário sobre a religiosidade popular do Baixo Minho. Taíde/Póvoa de Lanhoso: Confraria de Nossa Senhora do Porto de Ave, 2006. CAstro, Maria de Fátima - A Misericórdia de Braga. Assistência material e espiritual (das origens a cerca de 1910). Braga: Misericórdia de Braga, 2006. Guedes, Ana Isabel Marques Os Colégios dos Meninos Órfãos (séculos XVII-XIX): Évora, Porto e Braga. Lisboa: Imprensa de Ciências Sociais, 2006. Silva, Susana Serpa - Violência, desvio e exclusão na sociedade micaelense oitocentista (1842-1910). Ponta Delgada: Tese de Doutoramento apresentada à Universidade dos Açores, 2006. Ferraz, Norberto Tiago Gonçalves - Solidariedades na Misericórdia de Cabeceiras de Basto (1877-1930). Braga: Tese de Mestrado apresentada à Universidade do Minho, 2007. CAstro, Maria de Fátima - A Misericórdia de Braga. A assistência material no hospital de S. Marcos. Braga: Misericórdia de Braga, 2008. SÁ, Isabel dos Guimarães e LoPEs, Maria Antónia - História Breve das Misericórdias (1498-2000). Coimbra: Imprensa da Universidade, 2008. LoPES, Maria Antónia e PAIVA, José Pedro 
Por portaria do Ministério do Reino de 12 de Junho de 1876 foi ordenado que se procedesse a um inquérito minucioso às instituições de piedade e de beneficência. Cumpriu-se no distrito de Coimbra ao longo dos anos 1876 a 1878, resultando dois cadastros: Registo das instituições de beneficencia ${ }^{9} \mathrm{e}$ Registo geral das instituições de piedade ${ }^{10}$. Enfermam estas fontes de uma limitação de vulto: são omissas em relação às instituições sob administração pública directa. E em Coimbra havia dois grandes estabelecimentos: os Hospitais da Universidade e o Hospício dos Abandonados que, em Julho de 1872, se substituíra às rodas de todo o distrito. Além desses, como em todo o reino, os concelhos mantinham médicos, e por vezes também farmacêuticos e parteiras, que tratavam gratuitamente os doentes pobres. Todavia, porque estes cadastros permitem caracterizar com bastante rigor o universo associativo de índole beneficente e cultual do distrito, considerei ser importante explorá-los.

Na década de 1870 o distrito de Coimbra era composto por 17 concelhos, os mesmos que integra actualmente ${ }^{11}$, mas então com um total de 187 freguesias (são agora 209). O concelho de Coimbra era o maior em número de paróquias e em habitantes, seguindo-se, em população, o da Figueira da Foz. Nos restantes habitavam menos de 30.000 pessoas ou mesmo menos de 10.000, casos de Penela, Poiares e Mira.

(dir.) - Portugaliae Monumenta Misericordiarum 8. Tradição e modernidade: o período da monarquia constitucional (1834-1910). Lisboa: União das Misericórdias Portuguesas, 2010. AraúJo, Maria Marta Lobo de - A Misericórdia de Vila Viçosa de finais de Antigo Regime à República. Vila Viçosa: Misericórdia de Vila Viçosa, 2010. Esteves, Alexandra Patrícia Lopes - Entre o crime e a cadeia: violência e marginalidade no Alto Minho (1732-1870). Braga: Tese de Doutoramento apresentada à Universidade do Minho, 2010. Silva, Daniela Santos - Rituais e celebrações públicas da assistência em Setúbal, do final da Monarquia Constitucional à inauguração do Museu da Cidade, 1893-1961. Lisboa: Tese de Mestrado apresentada ao ISCTE-IUL, 2010. Não me refiro aqui aos estudos sobre associações de previdência, onde se englobam os socorros mútuos, seguros, caixas económicas, etc.

9 Arquivo da Universidade de Coimbra, Fundo do Governo Civil (TA/E4/T1/139).

${ }^{10}$ Arquivo da Universidade de Coimbra, Fundo do Governo Civil (TA/E4/T1/138).

${ }^{11}$ Os concelhos de Poiares e de Mira foram extintos em 1895 mas logo restaurados em 1898. Durante esses três anos o território do primeiro foi repartido pelos concelhos de Penacova e Lousã e o do segundo anexado ao de Cantanhede. 
Quadro 1 - Distribuição concelhia do número de freguesias e da população do distrito de Coimbra em 1876

\begin{tabular}{lrrrrr}
\hline \multicolumn{1}{c}{ Concelho } & Freg. & Fogos & Homens & Mulheres & Habitantes \\
\hline Arganil & 17 & 4817 & 10016 & 10795 & 20811 \\
Cantanhede & 14 & 7267 & 12735 & 13969 & 26704 \\
Coimbra & 30 & 11904 & 20895 & 23564 & 44459 \\
Condeixa & 10 & 2838 & 5511 & 5548 & 11059 \\
Figueira da Foz & 11 & 9883 & 16552 & 18375 & 34927 \\
Góis & 5 & 3028 & 4823 & 6447 & 11270 \\
Lousã & 5 & 2464 & 5016 & 5303 & 10319 \\
Mira & 1 & 1862 & 3317 & 3548 & 6865 \\
Miranda do Corvo & 4 & 2947 & 5633 & 5931 & 11564 \\
Montemor o Velho & 14 & 5754 & 10058 & 11122 & 21180 \\
Oliveira do Hospital & 19 & 5696 & 12375 & 11775 & 24150 \\
Pampilhosa & 10 & 2263 & 4988 & 5083 & 10071 \\
Penacova & 9 & 3672 & 7471 & 7787 & 15258 \\
Penela & 6 & 2475 & 4606 & 4924 & 9530 \\
Poiares & 4 & 1779 & 3262 & 3827 & 7089 \\
Soure & 12 & 4879 & 8999 & 9332 & 18331 \\
Tábua & 16 & 4352 & 8677 & 9255 & 17932 \\
Total & 187 & 77880 & 144934 & 156585 & 301519 \\
\hline
\end{tabular}

Fonte: Mello, Fernando Augusto de Andrade Pimentel de - Relatorio apresentado à Junta Geral do Districto de Coimbra na sessão ordinaria de 1877. Coimbra: Imprensa da Universidade, 1877.

\section{Moldura legal das instituições de piedade e beneficência}

Os governos liberais portugueses sempre distinguiram com clareza assistência e previdência. As instituições de piedade e beneficência eram tuteladas pelo Ministério do Reino e as de previdência, que englobavam as associações de socorros mútuos, montepios, seguros..., estavam sob a tutela do Ministério das Obras Públicas (por estranho que agora nos possa parecer). Os governantes sabiam que a solução do pauperismo passava pelas duas vertentes, mas consideravam que só a assistência era atribuição governamental, que devia, aliás, coadjuvar a caridade particular. 
No domínio da beneficência, o Estado oitocentista actuava de duas formas: com "administração primária e directa"12 e com administração secundária e indirecta. Através do Ministério do Reino, Juntas Distritais, Governos Civis e Administrações dos concelhos o Estado geria directamente: vários hospitais, incluindo os de Lisboa (os maiores do país), Coimbra e Caldas das Rainha; a Misericórdia de Lisboa; alguns asilos; e, em todo o reino, os partidos municipais médicos, farmacêuticos e obstétricos, o socorro aos expostos e os subsídios de amamentação a famílias pobres. Os expostos que eram tutelados pelas câmaras, o hospital das Caldas e os partidos camarários já eram administrados pelo Estado antes do século XIX. A administração primária e directa foi instaurada pelo Liberalismo nos restantes serviços, incluindo os enjeitados nos casos em que até então se encontravam a cargo das misericórdias.

A administração secundária e indirecta era exercida, como sempre havia sido, pelos agentes periféricos do poder central, agora os governadores civis, com atribuições mais latas do que tinham sido as dos corregedores e provedores das comarcas. As instituições de beneficência e piedade supervisionadas pelo Estado eram as misericórdias, hospitais, irmandades, confrarias, ordens terceiras e as que foram surgindo ao longo do século XIX: asilos, creches, dispensários, lactários, albergues nocturnos, etc. A tutela era pesada: todas essas instituições eram obrigadas a apresentar e a aguardar aprovação ministerial de estatutos, orçamentos, contas, despesas extraordinárias, resgate de aplicações financeiras, aquisições de bens imobiliários, contratações, etc.

As medidas fiscalizadoras dos governos liberais não corporizaram uma ruptura com a política anterior, como poderá parecer, atendendo às novidades administrativas e terminológicas. É que já durante o Antigo Regime as misericórdias e os hospitais estavam sob imediata protecção do soberano e se "até meados do século XVIII a tutela régia era em geral pouco interveniente, (...) a acção pombalina mudou este relacionamento, impondo-se, desde a década de 1750, uma forte ingerência da Coroa, comportamento

${ }^{12}$ Expressão utilizada na portaria de 12 de Abril de 1866 assinada por Joaquim António de Aguiar. 
que se prolongou pelos dois reinados seguintes"13. Por isso, o alvará de 18 de Outubro de 1806 foi repetidamente invocado durante a monarquia constitucional. Este diploma conferira às misericórdias, hospitais e rodas de expostos uniformidade e maior solidez económica, impusera novas práticas assistenciais e a inspecção regular das suas actividades. Quanto às confrarias e ordens terceiras, também foram alvo de progressivo controlo por parte do Estado a partir da $2^{\mathrm{a}}$ metade de Setecentos.

Com a implantação do novo regime político, “como o país não dispunha de meios para a criação de base de um novo sistema assistencial e, por outro lado, possuía uma rede bem disseminada de misericórdias, instituições arreigadas nos hábitos locais e dotadas de meios, a nova ordem constitucional considerou-as insubstituíveis, as pedras basilares do sistema nacional de beneficência que, por isso mesmo, não podia deixar entregues aos caprichos dos dirigentes locais" ${ }^{14}$.

Aplicando a portaria de 27 de Setembro de 1835, que ordenara a fiscalização dos "estabelecimentos de caridade e piedade" para "fazer cessar os escandalosos abusos", o decreto de 21 Outubro de 1836 mandou inspeccionar a administração dos seus bens próprios e rendimentos e obrigou-os, sob pena de extinção, a submeter anualmente os orçamentos à autoridade administrativa. Nenhuma destas instituições poderia "dispender rendimento algum sem prévia authorização do Administrador Geral", mais tarde designado governador civil. As "sobras" (rendimento que não era gasto) eram canalizadas para "os estabelecimentos de piedade e caridade que mais precisem, e que sejam de maior utilidade", para os salários dos professores do ensino primário e ainda, embora a lei geral o não explicitasse, para a construção de cemitérios.

O Código Administrativo de 1842 (em vigor até 1878) consagrou no seu artigo $226^{\circ}$ competir aos governadores civis: "Superintender todos os estabelecimentos de piedade e beneficencia, promovendo o seu melho-

${ }^{13}$ Lopes, Maria Antónia - Protecção social em Portugal na Idade Moderna. Coimbra: Imprensa da Universidade, 2010, p. 126.

${ }^{14}$ SÁ, Isabel dos Guimarães e Lopes, Maria Antónia - História Breve das Misericórdias Portuguesas, cit., p. 84-85. 
ramento, regulando a sua administração, fiscalisando as suas despezas e exercendo o direito de demittir os seus empregados, e dissolver as suas mesas, nomeando commissões que as substituam até nova eleição". Expressamente dirigido às irmandades e confrarias, o artigo $229^{\circ}$ determinava que ao governador civil pertencia "Approvar, modificar ou annullar as deliberações das juntas de parochia sobre a conveniencia de fazer contribuir as irmandades ou confrarias para as despesas parochiaes". "Approvar os orçamentos e regularisar definitivamente as contas das irmandades, confrarias e mais estabelecimentos pios e de beneficencia" e "Auxiliar com as sobras das rendas das irmandades ou confrarias, os estabelecimentos pios mais necessitados ou mais uteis, ouvindo as juntas de parochia e as camaras respectivas". No círculo concelhio, atribuía-se ao administrador a vigilância, inspecção e verificação das contas "dos diversos estabelecimentos de piedade, beneficencia e ensino publico" (artigo 248 ${ }^{\circ}$.

Depois, o decreto lei de 22 de Junho de 1866 obrigou à desamortização dos bens não necessários ao "desempenho das suas funcções" de "districtos, municipios, parochias, casas de misericordias, hospitaes, irmandades, confrarias, recolhimentos e quaesquer outros estabelecimentos pios ou de beneficencia, nacionaes ou estrangeiros". Esta desamortização de 1866 foi muito diferente da que se praticara na década de 1830. O Estado não expropriou as instituições, mas obrigou-as a alienar os imóveis de que não necessitavam para as suas actividades, aplicando-se o produto da venda em inscrições de crédito público cuja propriedade e juros continuavam a pertencer às instituições. É óbvio que os governantes procuravam compatibilizar as urgentes necessidades de dinheiro por parte do Estado com a salvaguarda das actividades dessas instituições, de que o país não podia prescindir. Simultaneamente, com a alienação dos imóveis, dificultava-se a apropriação pessoal dos bens e dos seus rendimentos por parte dos gestores ou suas clientelas, eliminavam-se as propriedades improdutivas, combatia-se o desleixo de gestão e a fiscalização tornava-se muito mais fácil. Veremos neste texto como, dez anos depois, fora aplicada a lei.

O Código Civil de 1867 definiu os institutos de piedade e beneficência como "pessoas morais" com individualidade jurídica, por terem fins de utilidade pública ou "utilidade publica e particular conjunctamente" e 
na condição de existirem legalmente ${ }^{15}$. Retomando legislação anterior, consignou as restrições na aquisição e conservação da propriedade, esclarecendo que no caso de extinção os bens seriam incorporados na fazenda nacional. A fim de agilizar os processos, o decreto de 22 de Outubro de 1868 transferiu a faculdade de aprovação dos estatutos e compromissos das associações de piedade e de beneficência, até então sujeitos à anuência régia, para os governadores civis.

Finalmente, por portaria de 6 de Dezembro de 1872, Rodrigues Sampaio ordenou que nos estatutos e compromissos das "associações de piedade e de beneficencia" doravante fundadas ou quando se procedesse à alteração dos já existentes "se estabeleça a obrigação de subsidiar o ensino primario da freguezia, quando careça desse auxilio, e bem assim de ser applicada a actos de beneficencia uma parte do rendimento da corporação, não inferior a um decimo da sua receita ordinaria, sendo esta verba applicada conforme a indicação do governador civil".

Em suma: os governos liberais uniformizaram, planificaram, policiaram e canalizaram rendimentos para as instituições assistenciais. Além disso, doaram-lhes património (sobretudo edifícios devolutos na sequência da extinção das ordens religiosas) e inseriram sempre importantes verbas para a beneficência nos orçamentos do Estado, das Juntas Distritais e dos Municípios. De facto, o regime monárquico oitocentista, no que toca ao seu programa de ajuda social, não foi um regime liberal, mas antes fortemente interventivo. Mas a eficácia da superintendência e inspecção assentava no empenho, competência e meios de que dispunham os governadores civis e os administradores dos concelhos. E estes ficaram sempre aquém das proclamações governamentais.

Ainda em Março de 1874 o governador do distrito de Coimbra se queixava que "difficilmente se consegue que os orçamentos [das câmaras municipais] sejam feitos nos prazos legaes, ou que venham organisados em

${ }^{15}$ Eram consideradas pessoas morais: o Estado, a Igreja, as câmaras municipais, as juntas de paróquia e os estabelecimentos de beneficência, de piedade e de instrução. Excluíam-se, assim, as associações de socorros mútuos, montepios, caixas económicas, etc., cujos objectivos se enquadravam na previdência e não na beneficência. Aliás, o art. $39^{\circ}$ é taxativo: "As associações de interesse particular são regidas pelas regras do contracto de sociedade". 
harmonia com as prescripções da Lei. O mesmo acontece com as contas, $\mathrm{e}$, relativamente às cobranças da receita, é quasi geral a falta de actividade e o desleixo, de que dão testemunho avultadas dividas activas, e a falta de pontualidade nos pagamentos". Quanto à administração paroquial, afirmava ser "má, em geral" "e poucos progressos e melhoramentos n'ella se notam: ainda assi, tem-se conseguido que a maior parte das respectivas Juntas tenham submettido á approvação os respectivos orçamentos" ${ }^{\prime 16}$.

Mais difícil era a fiscalização dos institutos de beneficência e de piedade. A fonte aqui explorada revela como a prática estava longe de corresponder ao clausulado legal. O questionário incluía as seguintes perguntas relativamente às "Contas da Gerencia": "Anno económico a que se refere a ultima conta apresentada" e "Anno económico a que se refere a ultima conta approvada".

Responderam às duas questões $83 \%$ das instituições de beneficência. Em média, não apresentavam contas há 4 anos, indo de zero a 27 , mas sendo esta situação, que respeita à Misericórdia de Arganil, um caso excepcional. Eliminando-o, temos uma variação que vai de zero a 15 anos, na Misericórdia de Vila Cova de Sub-Avô (actual Vila Cova de Alva, Arganil). O incumprimento era também da responsabilidade das autoridades, que chegavam a reter os livros enviados durante vários anos, sem que os examinassem. Assim, as contas das instituições de beneficência haviam sido aprovadas há 12 anos em média, com extremos de 0 e 27. Em 5 misericórdias a contabilidade não era fiscalizada há 20 ou mais anos: Arganil, Botão (Coimbra), Penela, Semide (Miranda do Corvo) e Soure.

A situação das confrarias era mais grave. Boa parte nunca fora fiscalizada porque não tinha contabilidade organizada ou, se a tinha, não a fazia chegar às autoridades. Os administradores dos concelhos desculpavam-se: "Não se tem tomado contas apesar das diligencias que se tem feito e que é devido a não haver uma escripturação regular, notando-se falta de pessoal habilitado" (Irmandade de Santo António, Cerdeira, Arganil). As contas "estão lançadas desde 1845 até 1873 sem comtudo terem sido apresentadas", escreve o

${ }^{16}$ OSORIO, Antonio de Gouvêa - Relatorio apresentado à Junta Geral do Districto de Coimbra na sessão ordinaria de 1874. Coimbra: Imprensa da Universidade, 1874, p. 25, 29. 
presidente da Câmara, servindo de Administrador, sobre a Confraria da Senhora da Boa Morte, de Miranda do Corvo. Ou então nada era possível saber-se porque, segundo se afirmava, os livros de contas haviam-se extraviado. Assim, as autoridades concelhias só conseguiram deslindar a data da última apresentação de contas em $67 \%$ dessas instituições, o que tinha sido feito em média há 5 anos, mas com intervalo de zero a 36 anos. Quanto à data da última aprovação, foi apurada apenas em $49 \%$ das irmandades. Nestas, e também porque com frequência os livros se eternizavam nas administrações concelhias ou distrital, a contabilidade não eram aprovada em média há 12 anos, indo de zero a 47, caso extremo da Irmandade de S. Braz, de Espariz (Tábua). Afirma-se acerca da Irmandade das Almas e Santos Passos, de Góis: "Desde 1865 a 1866 até 1875 a 1876 tem sido sempre enviadas ao Governo Civil do Districto as contas da confraria das almas, mas ainda não ha conhecimento de que tenham sido approvadas". E sobre as confrarias das Almas e da Senhora do Rosário, ambas de Mira: "Não pode responder aos quesitos sobre contas de gerencia, por que o livro, que podia elucidal-a para responder com precisão está ha 4 ou 5 annos no Governo Civil". Em oito confrarias do distrito, as últimas contas aprovadas datavam da década de 1840 .

Perante estes dados, resta concluir que a fiscalização efectiva da actividade das instituições de beneficência, e mais ainda nas de piedade, era ainda uma miragem na década de 1870 . Todavia, o facto de se terem elaborado estes notáveis cadastros não pode deixar de ser realçado como prova de grande esforço e competência administrativa. Com a sua análise, é possível quantificar com exactidão esse universo institucional, traçar a sua distribuição no espaço e estabelecer a sua dimensão humana e o que ela representava no conjunto da população. Conseguimos também (com rigor nos institutos assistenciais e com grande aproximação nos de piedade) determinar a sua situação patrimonial e financeira, aquilatar do cumprimento da lei de desamortização e avaliar a sua real importância no socorro às populações. É claro que, sendo embora uma fonte muito rica em informação, não é possível perguntar-lhe aquilo a que não pode responder, nomeadamente o que se relaciona com os institutos de beneficência geridos pelo Estado e, ainda, tudo o que respeita à previdência, cujas associações cresciam por estes anos. 


\section{Tipologia das instituições e sua distribuição}

Além dos já referidos Hospitais da Universidade de Coimbra e Hospício dos Abandonados, o distrito possuía nos seus 17 concelhos 23 instituições dedicadas à beneficência, sendo 18 misericórdias ${ }^{17}$, dois hospitais (um em Montemor-o-Velho e outro em Arganil), a Ordem Terceira de Coimbra e os Asilos da Infância Desvalida e de Mendicidade, ambos em Coimbra, a única cidade do distrito. Nem sempre a distinção entre institutos beneficentes e de piedade é clara, o que se reflecte na tipificação feita pelos administradores dos concelhos. Estes registaram 22 instituições de beneficência, incluindo a Ordem Terceira de Coimbra e a Confraria de Campos, em Montemor, mas excluindo a Ordem Terceira da Figueira e a Misericórdia do Botão, arroladas nas instituições de piedade. Face às actividades por elas desenvolvidas, considerei de índole assistencial a Misericórdia do Botão, a Ordem Terceira de Coimbra e a Confraria de Campos. Acerca desta última, esclarece o administrador ao responder sobre as instituições de piedade: "Como esta instituição tem um hospital, em que verdadeiramente consiste o fim da associação, vide por isso o Registro das instituições de beneficencia". Relativamente à Ordem Terceira de Coimbra, interroguei-me se deveria considerá-la um estabelecimento assistencial, visto que reservava os socorros aos seus membros. Tipifiquei-a assim, no entanto, devido à sua dimensão, com 500 irmãos de ambos os sexos, e à assistência que lhes prestava no seu hospital e ao domicílio ${ }^{18}$. Mantive a Ordem Terceira da Figueira da Foz nas instituições de piedade, pois a sua acção beneficente era modesta, representando 9 a $10 \%$ das suas despesas entre 1876 e $1880^{19}$.

Esta rede assistencial era na sua quase totalidade uma herança do Antigo Regime. Apenas cinco instituições haviam sido fundadas depois de 1834:

${ }^{17}$ Em rigor, as misericórdias eram também instituições de piedade, por serem confrarias (especialíssimas, é certo) e porque asseguravam actividades cultuais, mas a legislação classificava-as sempre (e com razão) como instituições de beneficência.

${ }^{18}$ Sobre esta Ordem Terceira, ver BARrico, Joaquim Simões - Noticia historica da Veneravel Ordem Terceira da Penitencia de S. Francisco. Coimbra: Typ. Reis Leitão, 1895.

${ }^{19}$ CASCÃo, Rui - Figueira da Foz e Buarcos entre 1861 e 1910. Permanência e mudança em duas comunidades do Litoral. Coimbra/Figueira da Foz: Minerva/Centro de Estudos do Mar, 1998, p. 487. Não muito superior, afinal, ao que representava nos gastos da Irmandade do Santíssimo Sacramento, 7 a 8\% nos anos 1870 (IDEM, ibidem, p. 486). 
o Asilo da Infância Desvalida em 1836, a Misericórdia da Figueira da Foz em 1839, o hospital da Ordem Terceira de Coimbra em 1852 (reservado aos irmãos), o Asilo de Mendicidade D. Pedro V em 1855 e o hospital público de Arganil em 1874 (para "os absolutamente pobres do concelho"). Todas as outras eram anteriores a 1800. E, saliente-se, só os asilos eram instituições tipicamente liberais.

No século XIX, e como sempre haviam sido, as misericórdias eram confrarias sob imediata protecção régia compostas por homens dos estratos médio e superior de cada localidade, constituídas por mandato do monarca ou com a sua autorização, e com regulamentos obrigatoriamente aprovados pelo poder central. Embora fossem confrarias, distinguiam-se das restantes pela natureza jurídica, que era civil, e pelas actividades, que eram de carácter espiritual mas também social e dirigidas para o exterior de si próprias. A acção das misericórdias integrava-se na doutrina católica, mas eram associações de leigos, ainda que também os clérigos nelas ingressassem, mas na qualidade de cristãos, como todos os outros. Assim sendo, as misericórdias estiveram sempre isentas da jurisdição eclesiástica, querendo isto dizer que nem os párocos nem os bispos tinham poder de intervenção legal na sua actividade, à excepção (e mesmo essa com frequência contestada) de pontuais inspecções dos locais de culto por parte dos bispos. Contudo, estes não tinham o poder de escolher os sacerdotes que asseguravam a acção espiritual das misericórdias, pois eram as Mesas dirigentes que os contratavam, considerando-os seus funcionários.

Estas instituições desempenharam ao longo dos tempos uma acção social vasta e multifacetada: administravam a quase totalidade dos hospitais do reino - tendendo a concentrar-se cada vez mais nessa vertente desde finais de Antigo Regime -, prestavam cuidados médicos domiciliários, distribuíam medicamentos gratuitos, enterravam pobres, dotavam órfãs, prestavam assistência material, jurídica e espiritual aos presos pobres, distribuíam esmolas, etc. ${ }^{20}$.

${ }^{20}$ Para uma visão sintética e actualizada da história e natureza das misericórdias portuguesas, ver SÁ, Isabel dos Guimarães e LoPEs, Maria Antónia - História Breve das Misericórdias..., cit., e os textos introdutórios dos volumes 3 a 8 de PAIVA, José Pedro (coord.) - Portugaliae Monumenta Misericordiarum. Lisboa: União das Misericórdias Portuguesas, 2004-2010. 
As misericórdias eram as instituições de assistência mais numerosas do nosso país, embora com fortes disparidades na sua distribuição territorial ${ }^{21}$. Também no distrito de Coimbra assim sucedia. Existentes em $71 \%$ dos concelhos, estavam ausentes nos de Condeixa, Mira, Penacova, Poiares e Tábua. Ausentes também em sete sedes de municípios: além dessas cinco vilas, nem Miranda do Corvo nem Oliveira do Hospital as possuíam, pois as Santas Casas desses concelhos estavam sediadas respectivamente em Semide (antigo couto e concelho) e em Galizes, freguesia que fora extinta e anexada à de Nogueira do Cravo. Isto é, em Oliveira do Hospital nem a sede do município nem nenhuma das sedes de freguesia possuía uma Misericórdia. Em contrapartida, cinco concelhos tinham mais do que uma, o que se explica por terem absorvido municípios extintos. No concelho de Montemor havia três misericórdias: na sede, em Tentúgal e em Pereira; o de Arganil tinha duas: nessa vila e em Vila Cova de Sub-Avô; o da Figueira da Foz contava com a jovem Misericórdia da Figueira e com a de Buarcos; e o de Soure tinha também duas, uma na sede do concelho e a outra em Vila Nova de Anços. $\mathrm{O}$ caso de Coimbra era um pouco diferente, devido à atipicidade da Misericórdia do Botão, instituição que nem instalações próprias possuía.

Confrarias e irmandades designavam o mesmo tipo de instituição, mas os textos oitocentistas emanados dos ministérios e administrações locais referem-se sempre às duas como se se tratasse de agremiações de natureza diferente. Em contrapartida, incluíam as ordens terceiras nesse grupo designado "irmandades e confrarias", o que era incorrecto.

Nos finais do Antigo Regime, a maioria das irmandades cultuava o Santíssimo Sacramento, as Almas do Purgatório e a Virgem Maria. "É evidente que a adesão às confrarias se prendia com os medos do Além e a busca de conforto e protecção por parte das populações, mas um conjunto de razões mais concretas explica a sua multiplicação por todo o país e o seu império: menor selectividade social, por comparação

${ }^{21}$ Em 1866, no distrito de Braga, só $61 \%$ dos concelhos estavam dotados de uma instituição de beneficência (ver LoPEs, Maria Antónia e PAIVA, José Pedro (dir.) - Portugaliae Monumenta Misericordiarum 8. Tradição e modernidade: o período da monarquia constitucional (1834-1910). Lisboa: União das Misericórdias Portuguesas, 2010, doc. 245). No Sul do país a rede de misericórdias era mais densa. No mesmo ano, no distrito de Portalegre, todos os concelhos possuíam uma Santa Casa e alguns mais do que uma (IDEM, ibidem, doc. 246). 
com as misericórdias, abertura às mulheres, concessão de indulgências, apoio espiritual e material proporcionado aos confrades, facilitação de acesso ao crédito, garantia de enterramento solene e de sufrágios, sentimento de pertença, possibilidades de socialização e de acção proporcionadas por estas agremiações, etc. Responsável em grande parte pela multiplicidade de confrarias numa mesma comunidade era a possibilidade de multifiliação"22 As ordens terceiras eram comunidades de leigos instituídas por bulas ou breves papais, regidas por uma regra aprovada pela Santa Sé e vinculadas a uma ordem religiosa. Os seus membros, de ambos os sexos, faziam noviciado, profissão e recebiam hábito. Ao contrário das irmandades, "não pretendiam, prioritariamente, fomentar o culto público, embora construíssem igrejas e realizassem festividades religiosas. A caridade também não era a sua principal missão. Praticavam-na, mas destinada aos irmãos, e as mais ricas abriram recolhimentos, escolas e importantes hospitais que reservavam aos membros da ordem. O verdadeiro objectivo das ordens terceiras era o aperfeiçoamento espiritual dos Irmãos"23.

Em 1840 havia no distrito de Coimbra 378 confrarias. Vinte anos depois esse número baixara para 324, em Janeiro de 1869 para 290 e em 1872 restavam $218^{24}$. Esta importante redução integrava-se no contexto nacional. No distrito de Viana do Castelo houve uma quebra de 24\% entre 1861 e $1871^{25}$. Nos mesmos anos, em Coimbra essa quebra foi de $33 \%$.

Os administradores dos concelhos do distrito de Coimbra de 1876-1878 identificaram 199 instituições de piedade (irmandades, confrarias e a Ordem Terceira da Figueira da Foz). Como duas estavam já anexadas nas receitas, despesas e número de irmãos, restavam 198. Depois, e até 1902, pelo menos nove delas foram legalmente extintas ${ }^{26}$. Assim, nos 72 anos que decorreram entre 1840 e 1902 o distrito de Coimbra perdeu 50\% das confrarias do seu território. Mas essa redução fora importante sobretudo até inícios da década de 1870, quando foi suprimida a maioria delas (42\% entre 1840 e 1872).

${ }^{22}$ Lopes, Maria Antónia - Protecção social..., cit., p. 105-106.

${ }^{23}$ IDEM, ibidem, p. 109-110.

${ }^{24}$ Roque, João Lourenço - Classes populares no distrito de Coimbra no século XIX (1830-1870). Contributo para o seu estudo. Coimbra: Tese de doutoramento apresentada à Universidade de Coimbra, 1982, p. 615-618.

${ }^{25}$ CASCÃo, Rui - Vida quotidiana e sociabilidade, cit., p. 541.

${ }^{26}$ Essas 9 supressões foram registados no cadastro de 1876/78. 
João Roque já assinalou o facto, "traduzindo uma significativa decadência destes estabelecimentos ou a sua redução por via administrativa"27. Com efeito, se em algumas as autoridades se limitaram a verificar o seu efectivo desaparecimento, para a maioria foi a lógica de racionalização de recursos que determinou a sua supressão que, como se viu, a lei previa.

Em 1876/78, só existiam duas ordens terceiras no distrito, ambas franciscanas e implantadas nos maiores núcleos populacionais, Coimbra e Figueira da Foz. As restantes instituições pias intitulavam-se maioritariamente irmandade (57\%), em detrimento da designação de confraria. As que cultuavam o Santíssimo Sacramento representavam $41 \%$ da totalidade, seguindo-se as irmandades ou confrarias das Almas com 17\% e as de invocação mariana com 15\%. Isto é, Santíssimo Sacramento, Almas do Purgatório e Virgem Maria, cultos impulsionados pela Contra-Reforma católica, reuniam $74 \%$ destas agremiações do último terço do século XIX. Nem outro panorama seria de esperar, pois não só esses cultos se tinham enraizado profundamente nas populações, como também $89 \%$ das instituições pias do distrito eram de fundação anterior a 1834 e $83 \%$ anteriores a 1800 . O culto eucarístico e mariano, assim como a devoção ao Coração de Jesus e ao Coração de Maria também fortemente incentivados pela Igreja da $2^{\mathrm{a}}$ metade de Oitocentos $^{28}$, mas no distrito de Coimbra, em 1876-1878, eram ainda inexistentes as invocações do Coração de Jesus e Coração de Maria e só duas confrarias procuravam difundir o dogma da Imaculada Conceição, proclamado em 1854. É que na década de 1870 estava-se ainda no início da vaga do militantismo religioso e da revitalização do associativismo católico.

Se entre as 160 irmandades e ordens terceiras recenseadas no distrito de Lisboa em 1888, subsistia "uma escassa minoria" de carácter socioprofissional ${ }^{29}$, no de Coimbra já tinham desaparecido vinte anos antes. O fenómeno está obviamente relacionado com a extinção das corporações

${ }^{27}$ RoQue, João Lourenço - Classes populares no distrito de Coimbra ..., cit., p. 617.

${ }^{28}$ Ver Neto, Vítor - O Estado, a Igreja e a sociedade em Portugal (1832-1911). Lisboa: Imprensa Nacional-Casa da Moeda, 1998, p. 457-465. Clemente, Manuel - Persistências e redefinições in Azevedo, Carlos Moreira (dir.) - História Religiosa de Portugal 3. Religião e Secularização, coord. de Manuel Clemente e António Matos Ferreira. Lisboa: Círculo de Leitores, 2002, p. 114-115.

${ }^{29}$ Penteado, Pedro - Confrarias, cit., p. 466. 
de ofícios. Na verdade, podem ter sobrevivido algumas, ocultas por outra designação, mas a reconversão mais usual terá sido em associações de socorros mútuos, em franca expansão na segunda metade do século ${ }^{30}$.

Embora em número superior ao das freguesias do distrito, isso não impedia que existissem 43 paróquias $(23 \%)$ que não possuíam qualquer instituição confraternal: 6 nos concelhos de Arganil, Pampilhosa da Serra e Soure, 5 em Coimbra e em Cantanhede ${ }^{31}, 4$ em Oliveira do Hospital, 2 em Condeixa, Góis e Penela e uma na Figueira, Lousã, Montemor-o-Velho, Poiares e Tábua. Proporcionalmente ao número de freguesias, os concelhos com maior número de paróquias privadas de sociabilidade confraternal eram os da Pampilhosa com $60 \%$ e de Soure com 50\%. Seguiam-se Góis com 40\%, Cantanhede com 36\%, Arganil com 35\%, Penela com $33 \%$ e Poiares com $25 \%$. Os restantes estavam abaixo da média distrital. No concelho de Coimbra, $83 \%$ das suas 30 paróquias possuíam irmandades. Os 100\% eram atingidos em Mira, Miranda do Corvo e Penacova, o que só é expressivo neste último concelho de 9 freguesias, pois os outros dois eram constituídos apenas por uma e quatro paróquias. A freguesia de Santa Cruz (cidade de Coimbra) mantinha sete confrarias e em Eiras (concelho de Coimbra) existiam quatro. Possuíam três as paróquias de Alhadas (Figueira), Carapinheira (Montemor), Coja (Arganil), Ervedal (Oliveira do Hospital), Góis, Portunhos (Cantanhede) e Sé Nova (cidade de Coimbra). Havia ainda povoações que não eram sequer freguesias mas mantinham irmandades activas, como sucedia em Pena (freguesia de Portunhos), onde funcionavam duas.

${ }^{30}$ Ver RoQue, João Lourenço - O "mundo do trabalho" e o associativismo em Coimbra no século XIX (1850-1870). Ler História 41 (2001) 183-227. Para outras regiões: GoodoLPHIM, Costa - A Associação. Lisboa: Typ. Universal, 1876. Pereira, José Pacheco - A origem do movimento operário no Porto: as associações mutualistas (1850-70). Análise Social 65 (1981) 135-151. Pereira, Miriam Halpern - Artesãos, operários e o liberalismo - dos privilégios corporativos para o direito ao trabalho. Ler História 14 (1988) 41-86. Alves, Jorge Fernandes - O emergir das associações industriais no Porto (meados do século XIX). Análise Social 136-137 (1996), 527-544. Pereira, Miriam Halpern - As origens do Estado-Providência em Portugal: as novas fronteiras entre público e privado. Ler História 37 (1999) 45-61. IDEM - Mutualismo e a origem do seguro social in VAZ, Maria João; ReLVAs, Eunice; PINHEIRo, Nuno (org.) - Exclusão na História. Oeiras: Celta, 2000, p. 201-213.

${ }^{31}$ Sendo uma delas Ançã, o que é estranho numa localidade de boa dimensão e que fora sede de concelho. 
A intensidade da sociabilidade confraternal não se avalia apenas pelo número de agremiações, mas também, ou sobretudo, pela sua dimensão demográfica.

\section{Número de associados}

No conjunto das instituições de beneficência do distrito, o número de associados atingia os 3.013, com uma média de 137. Mas era a Ordem Terceira de Coimbra, com 500 membros, que fazia aumentar estas cifras. Excluindo-a, a dimensão média destas instituições baixa para 120 . As misericórdias, instituições elitistas, possuíam numerus clausus, não admitiam multifiliações nem membros do sexo feminino, pois foi só em 1872 (pelo citado decreto 6 de Dezembro) que passou a ser possível a sua admissão, retomando-se, talvez na ignorância do facto, o que se praticara nas suas longínquas origens.

Quadro 2 - Número de irmãos das misericórdias

\begin{tabular}{lc|lc}
\hline \multicolumn{1}{c}{ Misericórdia } & Membros & \multicolumn{1}{c}{ Misericórdia } & Membros \\
\hline Arganil & 146 & Pampilhosa & 110 \\
Botão & 207 & Penela & 38 \\
Buarcos & 130 & Pereira & 70 \\
Cantanhede & 70 & Semide & 58 \\
Coimbra & 300 & Soure & 158 \\
Figueira & 104 & Tentúgal & 91 \\
Galizes & 80 & Vila Cova de Sub-Avô & 181 \\
Góis & 80 & Vila Nova de Anços & 43 \\
Lousã & 109 & \multicolumn{2}{|c}{ Total } \\
\cline { 3 - 4 } Montemor-o-Velho & 200 & \multicolumn{2}{c}{} \\
\cline { 3 - 4 } & & \multicolumn{2}{c}{} \\
\cline { 3 - 4 } & & &
\end{tabular}

O número de irmãos da Santa Casa do Botão revela que não funcionava segundo as regras selectivas das misericórdias, indiciando-se, uma vez mais, que esta irmandade não era propriamente uma Misericórdia. A maior era a da cidade e a mais diminuta a de Penela, sendo a dimensão média de 116, excluindo deste cálculo a Misericórdia do Botão. 
Ignorando mais uma vez essa instituição, os irmãos das misericórdias representavam $1,4 \%$ da população masculina do distrito e $1,7 \%$ da população masculina dos concelhos onde existiam misericórdias $(1,9 \%$, se considerarmos a do Botão). Uma escassa minoria da população, portanto, como as misericórdias sempre desejaram para manter intacto o seu prestígio e o distanciamento em relação às outras agremiações. Destacava-se o concelho de Montemor, seguido do de Arganil, com índices de pertença bastante mais elevados, o que se explica pelo facto de possuírem mais do que uma Santa Casa.

Quadro 3 - Membros das misericórdias por concelhos

\begin{tabular}{|c|c|c|c|c|c|}
\hline Concelho & $\begin{array}{l}\mathrm{N}^{0} \mathrm{~s} \\
\text { abs. }\end{array}$ & $\begin{array}{l}\text { \% Pop. } \\
\text { Masc. }\end{array}$ & Concelho & $\begin{array}{c}\mathrm{N}^{0} \mathbf{s} \\
\text { abs. }\end{array}$ & $\begin{array}{l}\text { \% Pop. } \\
\text { Masc. }\end{array}$ \\
\hline Arganil & 327 & 3,26 & Montemor o Velho & 361 & 3,59 \\
\hline Cantanhede & 70 & 0,55 & Oliveira do Hospital & 80 & 0,65 \\
\hline Coimbra (c/ Mis ${ }^{\mathrm{a}}$ do Botão) & 507 & 2,43 & Pampilhosa & 110 & 2,21 \\
\hline Coimbra (s/ Mis ${ }^{\mathrm{a}}$ do Botão) & 300 & 1,44 & Penacova & & 0,00 \\
\hline Condeixa & & 0,00 & Penela & 38 & 0,83 \\
\hline Figueira da Foz & 234 & 1,41 & Poiares & & 0,00 \\
\hline Góis & 80 & 1,66 & Soure & 201 & 2,23 \\
\hline Lousã & 109 & 2,17 & Tábua & & 0,00 \\
\hline Mira & & 0,00 & Total (c/ Mis ${ }^{\text {a }}$ do Botão) & 2175 & 1,50 \\
\hline Miranda do Corvo & 58 & 1,03 & Total (s/ Mis ${ }^{\mathrm{a}}$ do Botão) & 1968 & 1,36 \\
\hline
\end{tabular}

O panorama muda radicalmente quando passamos a analisar as confrarias. Se o número destas instituições declinara acentuadamente, não significa que os seus membros tivessem diminuído. Pelo contrário. Em 1869 existiam no distrito 30.746 ou 30.781 irmãos que se distribuíam por 225 instituições pias $^{32}$. Ora, em 1876-78, e excluindo as ordens terceiras, 189 confrarias agrupavam 33.944 irmãos. Com as duas ordens terceiras, atingem-se as 34.970 pessoas, um universo 16 vezes maior do que o das misericórdias. As confrarias, no verdadeiro sentido da palavra, eram constituídas em média por 180 confrades; abrangendo as ordens terceiras, o número médio

\footnotetext{
${ }^{32}$ Roque, João Lourenço - Classes populares no distrito de Coimbra ..., cit., p. 616-617.
} 
de irmãos subia para 183. Cerca de 10 anos antes, com um número maior de instituições, a sua dimensão populacional era, naturalmente, menor: 137. Em geral, as confrarias admitiam homens e mulheres, mas a fonte não permite perceber quantas estão nessas circunstâncias nem qual a proporção dos dois sexos.

Considerando o número de confrades, como em tantas outras vertentes, as instituições de piedade eram heterogéneas. Assim, deparamo-nos com a Confraria do Santíssimo, de Outil (Cantanhede), composta por 24 membros e com a Irmandade das Almas, de Quiaios (Figueira), com 1.873. Além desta, existiam outras três com mais de 1.000 irmãos: a Confraria das Almas, de Cadima (Cantanhede), com 1.200; a Confraria de Leigos, de Lorvão (Penacova), com 1.207; e a Confraria das Almas, de Mira, com 1.300. Estas grandes confrarias eram-no já em 1869. Nesse ano as que albergavam mais de um milhar de membros eram a Confraria de Leigos, de Lorvão, com 1.164, a Confraria das Almas, de Mira, com 1.252 e a Irmandade das Almas, de Quiaios, com 1.882 ${ }^{33}$. Salvo esta última, todas aumentaram o número de confrades. Continuavam a predominar, contudo, as instituições de pequena dimensão, mesmo incluindo neste universo as ordens terceiras: $48 \%$ tinham menos de 100 membros e $77 \%$ menos de 200. As que congregavam mais de um milhar de confrades representavam $2 \%{ }^{34}$.

Observe-se intensidade da sociabilidade confraternal, não esquecendo que era possível e vulgar pertencer a mais do que uma confraria. Assim, os quadros que se seguem elucidam-nos sobre a intensidade da pertença e não sobre o número de pessoas diferentes que se congregavam nessas instituições.

Lendo a coluna do quadro 5 que nos informa sobre a proporção de instituições relativamente à população, destacam-se pela debilidade do seu universo confraternal, os concelhos de Mira, Poiares e Soure. Mas se atendermos ao número de confrades por instituição e, mais significativo, ao seu peso percentual na população, percebe-se que só Poiares e, mais ainda, o concelho de Soure, tinham índices de sociabilidade confra-

\footnotetext{
33 IDEM, ibidem, p. 685.

${ }^{34}$ Dez confrarias não declararam o número dos seus membros.
} 
Quadro 4 - Distribuição concelhia das instituições e seus membros

\begin{tabular}{lrrrrrr}
\hline \multicolumn{1}{c}{ Concelho } & $\begin{array}{c}\text { Conf. } \\
\text { e OT }\end{array}$ & Mis. & $\begin{array}{c}\text { Irmãos } \\
\text { Cf+OT }\end{array}$ & $\begin{array}{c}\text { Irmãos } \\
\text { Mis }\end{array}$ & $\begin{array}{c}\text { TT } \\
\text { Inst }\end{array}$ & $\begin{array}{c}\text { TT } \\
\text { irmãos }\end{array}$ \\
\hline Arganil & 14 & 2 & 1805 & 327 & 16 & 2132 \\
Cantanhede & 13 & 1 & 2771 & 70 & 14 & 2841 \\
Coimbra & 43 & 2 & 7625 & 507 & 45 & 8132 \\
Condeixa a Nova & 9 & 0 & 1116 & 0 & 9 & 1116 \\
Figueira da Foz & 14 & 2 & 4996 & 234 & 16 & 5230 \\
Góis & 5 & 1 & 565 & 80 & 6 & 645 \\
Lousã & 6 & 1 & 1584 & 109 & 7 & 1693 \\
Mira & 2 & 0 & 1882 & 0 & 2 & 1882 \\
Miranda do Corvo & 6 & 1 & 654 & 58 & 7 & 712 \\
Montemor o Velho & 20 & 3 & 2473 & 361 & 23 & 2834 \\
Oliveira do Hospital & 19 & 1 & 2089 & 80 & 20 & 2169 \\
Pampilhosa da Serra & 4 & 1 & 1143 & 110 & 5 & 1253 \\
Penacova & 14 & 0 & 4094 & 0 & 14 & 4094 \\
Penela & 4 & 1 & 421 & 38 & 5 & 459 \\
Poiares & 3 & 0 & 222 & 0 & 3 & 222 \\
Soure & 6 & 2 & 237 & 201 & 8 & 438 \\
Tábua & 18 & 0 & 1293 & 0 & 18 & 1293 \\
\hline Total & 200 & 18 & 34970 & 2175 & 218 & 37145 \\
\hline
\end{tabular}

Quadro 5 - Peso demográfico dos confrades (misericórdias, confrarias e ordens terceiras)

\begin{tabular}{lccc}
\hline \multicolumn{1}{c}{ Concelho } & $\begin{array}{c}\text { Instituições/ } \\
\text { /População } \\
(\mathbf{\%})\end{array}$ & $\begin{array}{c}\text { Confrades/ } \\
\text { /nstituição } \\
\text { (média) }\end{array}$ & $\begin{array}{c}\text { Confrades / } \\
\text { /População } \\
\text { (\%) }\end{array}$ \\
\hline Arganil & 0,08 & 133 & 10,24 \\
Cantanhede & 0,05 & 203 & 10,64 \\
Coimbra & 0,10 & 181 & 18,29 \\
Condeixa a Nova & 0,08 & 124 & 10,09 \\
Figueira da Foz & 0,05 & 327 & 14,97 \\
Góis & 0,05 & 108 & 5,72 \\
Lousã & 0,07 & 242 & 16,41 \\
Mira & 0,03 & 941 & 27,41 \\
Miranda do Corvo & 0,06 & 102 & 6,16 \\
Montemor o Velho & 0,11 & 123 & 13,38 \\
Oliveira do Hospital & 0,08 & 108 & 8,98 \\
Pampilhosa da Serra & 0,05 & 251 & 12,44 \\
Penacova & 0,09 & 292 & 26,83 \\
Penela & 0,05 & 92 & 4,82 \\
Poiares & 0,04 & 74 & 3,13 \\
Soure & 0,04 & 55 & 2,39 \\
Tábua & 0,10 & 72 & 7,21 \\
\hline Total & 0,07 & 170 & 12,3 \\
\hline
\end{tabular}


ternal muito baixos. O concelho de Mira, constituído por uma freguesia, mas mantendo activas duas confrarias, era aquele que atingia o máximo no coeficiente confrades/população. Era também muito intensa a sociabilidade confraternal no concelho de Penacova. O facto não se explica apenas pela pequena e média dimensão demográfica desses dois concelhos. Em vários dos mais populosos - que eram, por ordem decrescente, Coimbra, Figueira, Cantanhede, Oliveira do Hospital, Montemor e Arganil - a proporção de moradores que pertencia a uma confraria, ordem terceira ou misericórdia era elevada. Sobressai o concelho de Coimbra, com cerca de 44.500 habitantes, congregando $18 \%$ em instituições de piedade e beneficência.

\section{Desamortização}

Em 1876 haviam passado dez anos sobre a legislação que decretara a desamortização dos bens das instituições pias e beneficentes não necessários às suas actividades. Neste inquérito uma das questões que se queria aclarar era, precisamente, o cumprimento dessa determinação legal.

Os administradores dos concelhos conseguiram apurar o valor dos bens sujeitos a desamortização mas ainda não desamortizados de 19 instituições de assistência, mas só 9 possuíam elementos sobre o valor do que já fora vendido. Totalizava o primeiro montante 69.031 .792 réis e o segundo 61.828.124. À primeira vista, parece, pois, que os bens imóveis mais valiosos tinham sido já alienados. Contudo, este resultado está viciado pelas lacunas documentais e porque engloba os resultados da desamortização efectuada pela Misericórdia de Coimbra, que era a instituição mais rica e já alienara bens no valor de 34.758 .562 réis, correspondentes a $72 \%$ do património obrigado à desamortização ${ }^{35}$.

${ }^{35}$ Os dirigentes da Misericórdia de Coimbra há muito que preferiam libertar a instituição de imóveis, investindo em operações de crédito (Lopes, Maria Antónia - Pobreza, assistência..., cit., p. 134-135) e quando em inícios da década de 1860 se aventava a ideia da desamortização dos bens das misericórdias, defenderam-na abertamente (IDEM As Misericórdias: de D. José ao final do século XX, cit., p. 88). 
Se observarmos apenas os outros estabelecimentos beneficentes, os resultados são muito distintos: com bens sujeitos a desamortização num total (sem dúvida, subvalorizado) de 82.641 .183 réis, só se desamortizara $33 \%$ desse património. Já se suspeitava que assim teria sucedido em múltiplas misericórdias ${ }^{36}$. Estudos monográficos posteriores apontam no mesmo sentido ${ }^{37}$.

Nas confrarias, o incumprimento da lei é ligeiramente maior. Os bens declarados sujeitos a desamortização perfazem 90.513.984 réis, o que está, mais uma vez, aquém da realidade, pois só é conhecido o valor dos bens já desamortizados de 24 instituições - somando pouco mais de 29 contos e o montante dos bens que faltava desamortizar de 114 irmandades, o qual ultrapassava um pouco os 61 contos. Com estes dados, conclui-se que as confrarias ainda não tinham desamortizado $68 \%$ dos imóveis visados pela legislação.

\section{Património}

O património detido pelas instituições de beneficência do distrito de Coimbra abeirava-se dos 798 contos. Em média, possuíam bens no valor de 34,7 contos, mas este montante está claramente distorcido pela opulência da Misericórdia de Coimbra, mais rica do que todas as outras reunidas. Com efeito, a Santa Casa de Coimbra possuía 58\% do valor patrimonial das instituições beneficentes não estatais do distrito. Sem ela, o valor total era de 339,1 contos sendo a riqueza média desses estabelecimentos de 15,4 contos.

\footnotetext{
${ }^{36}$ Cf. SÁ, Isabel dos Guimarães e Lopes, Maria Antónia - História Breve das Misericórdias..., cit., p. 81-82, 90-92.

${ }^{37}$ Ver AraúJo, Maria Marta Lobo de - A Misericórdia de Vila Viçosa ..., cit., p. 93-95.
} 
Quadro 6-Valor patrimonial das instituição de beneficência do distrito de Coimbra em 1876/78

\begin{tabular}{|c|c|c|c|}
\hline Inst & Réis & Instituição & Réis \\
\hline Misericórdia & 458.812 .986 & Mis & 4.980 .870 \\
\hline & & & \\
\hline dro V (Coimbra) & 54.710 .440 & Vila Nova de Anços & 4.721 .000 \\
\hline & & & \\
\hline $\begin{array}{l}\text { de Campos (Montemor) } \\
\text { Asilo de Infância }\end{array}$ & 54.350 .000 & Misericórdia de Cantanhede & 4.598 .181 \\
\hline Desvalida (Coimbra) & 42.053 .000 & Misericórdia de Arganil & 3.687 .934 \\
\hline Misericórdia da Figueira & 37.745 .600 & Misericórdi & 3.592 .760 \\
\hline de Pereira & 28.013 .000 & Misericórdi & 2.909 .910 \\
\hline Misericórdia de Tentúgal & 25.504 .365 & Misericórdia do Botão & 1.862 .665 \\
\hline Misericórdia de Montemor & 18.48 & Misericórdia de Góis & 1.280 .000 \\
\hline Misericórdia de Soure & 13.796 .411 & Misericórdia da Lousã & 805.642 \\
\hline & & & \\
\hline de $\mathrm{S}$ & 13.765 .300 & Misericórdia da Pampilhosa & 493.695 \\
\hline tal da Ordem & & & \\
\hline Terceira (Coimbra) & 13.070 .000 & & 100.000 \\
\hline Misericórdia de Galizes & 8.603 .800 & Total & 7.945 .050 \\
\hline
\end{tabular}

Os valores indicados incluem património ilícito, isto é, os bens ainda retidos mas obrigados a desamortização. Considerando apenas o que era legalmente detido, obtemos um total de 728,9 contos se englobarmos a Misericórdia de Coimbra ou de 283,6 com a sua exclusão.

Já vimos que os bens sujeitos a desamortização das instituições de beneficência do distrito, e excluindo a Santa Casa coimbrã, atingiam os 90,5 contos, o que equivale a $27 \%$ do valor total do seu património. Assim sendo, e mesmo levando em conta que os bens passíveis de desamortização seriam superiores ao valor apurado, não restam dúvidas que a lei de 22 de Junho de 1866, mesmo que tivesse sido integralmente cumprida, estava longe de provocar a total ruína destes estabelecimentos, como tantas vezes se afirmou. Recorde-se que esta desamortização não implicou a expropriação dos bens, mas a aplicação do produto da venda em títulos de dívida pública, cuja propriedade e juros eram das instituições. Na verdade, não foi a desamortização, em si mesma, que arruinou as misericórdias e outras instituições, mas a crise financeira do Estado de finais do século e 
a inflação, que se irá prolongar pela década de 1920. Acresce que os juros dos títulos de dívida pública foram reduzidos em 30\% em 1892 e, como é óbvio, a enorme inflação desvalorizou de forma brutal o seu valor ${ }^{38}$.

Quadro 7 - Estrutura patrimonial da Misericórdia de Coimbra e restantes instituições de beneficência do distrito em 1876/78

\begin{tabular}{|c|c|c|c|c|c|c|}
\hline \multirow[b]{2}{*}{ Tipo de bens } & \multicolumn{3}{|c|}{ Misericórdia de Coimbra } & \multicolumn{3}{|c|}{ Restantes instituições } \\
\hline & Réis & $\begin{array}{l}\text { Com } \\
\text { ilícitos } \\
(\%)\end{array}$ & $\begin{array}{l}\text { Bens } \\
\text { lícitos } \\
(\%)\end{array}$ & Réis & $\begin{array}{l}\text { Com } \\
\text { ilícitos } \\
(\%)\end{array}$ & $\begin{array}{l}\text { Bens } \\
\text { lícitos } \\
(\%)\end{array}$ \\
\hline $\begin{array}{l}\text { Capitais mutuados } \\
\text { por escritura } \\
\text { pública }\end{array}$ & 237.687 .019 & 51,8 & 53,4 & 50.967 .519 & 15,0 & 18,0 \\
\hline $\begin{array}{l}\text { Títulos de dívida } \\
\text { pública, recebidos } \\
\text { pelos bens }\end{array}$ & & & & & & \\
\hline desamortizados & 106.550 .000 & 23,2 & 23,9 & 55.850 .000 & 16,5 & 19,7 \\
\hline $\begin{array}{l}\text { Títulos de dívida } \\
\text { pública de outras } \\
\text { proveniências }\end{array}$ & 55.650 .000 & 12,1 & 12,5 & 71.015 .200 & 20,9 & 25,0 \\
\hline $\begin{array}{l}\text { Bens imóveis } \\
\text { isentos da } \\
\text { desamortização }\end{array}$ & 18.000 .000 & 3,9 & 4,0 & 46.524 .000 & 13,7 & 16,4 \\
\hline $\begin{array}{l}\text { Papéis de } \\
\text { crédito de } \\
\text { estabelecimentos }\end{array}$ & & & & & & \\
\hline particulares & 20.000 .000 & 4,4 & 4,5 & 44.298 .000 & 13,1 & 15,6 \\
\hline Bens móveis & 4.581 .090 & 1,0 & 1,0 & 9.657 .020 & 2,8 & 3,4 \\
\hline Dividas activas & 2.884 .706 & 0,6 & 0,6 & 5.248 .704 & 1,5 & 1,9 \\
\hline $\begin{array}{l}\text { Bens imóveis a } \\
\text { desamortizar }\end{array}$ & 13.460 .171 & 2,9 & & 55.571 .621 & 16,4 & \\
\hline $\begin{array}{l}\text { Total do } \\
\text { património detido }\end{array}$ & 458.812 .986 & 100,0 & & 339.132 .064 & 100,0 & \\
\hline $\begin{array}{l}\text { Total do } \\
\text { património isento } \\
\text { de desamortização } \\
\text { (lícito) }\end{array}$ & 445.352 .815 & & 100,0 & 283.560 .443 & & 100,0 \\
\hline
\end{tabular}

${ }^{38}$ Lopes, Maria Antónia - As Misericórdias: de D. José ao final do século XX, cit., p. 89, 94-97. 
Apesar do muito que faltava desamortizar, o grosso do património destas instituições consistia já em capital investido em crédito oneroso. $\mathrm{Na}$ Misericórdia de Coimbra representava 92\% do seu património e nas restantes $67 \%$. O facto explica-se porque, como foi dito, a Misericórdia de Coimbra desde há muito preferia investir no crédito, vendendo as propriedades de que não carecia para as suas actividades. Em 1827 o capital investido no ágio alcançava 94\% do património, baixando um pouco, para $91 \%$, em $1846^{39}$. Excluindo as somas resultantes da desamortização, obrigatoriamente canalizadas para títulos de dívida pública, a rubrica de capitais colocados a juros em 1876-78 continuava a ser maioritária na Santa Casa coimbrã, onde atingia $68 \%$ do seu valor patrimonial, alcançando 50\% nas outras instituições de beneficência.

Note-se que em 1876/78 os imóveis sujeitos a desamortização detidos pela Misericórdia de Coimbra eram residuais. Esta instituição cumprira a lei. Outro tipo de gestão era adoptada pelos demais institutos de caridade. A diferença é flagrante se confrontarmos os valores percentuais dos seus bens imóveis com os da Misericórdia coimbrã. Englobando os que devia vender, nesta última representavam 6,9\%. Nas restantes equivaliam a 30\%.

Se bem que a fonte peque por defeito, pois omite os valores patrimoniais de 17 instituições pias, é indubitável (o que, aliás, não surpreende) que eram incomparavelmente mais pobres do que as de beneficência. Num total de 181, reuniam um património no valor de 271,9 contos, ou de 210,8 contos, se excluirmos os bens que estavam obrigados a desamortizar. A sua riqueza média era de 1,5 ou 1,2 contos. Confronte-se com a dos institutos beneficentes, cuja fortuna média, sem contar com a Misericórdia de Coimbra, era dez vezes superior, pois ia de 12 a 15 contos.

A fragilidade económica das agremiações pias ainda mais se evidencia se as distribuirmos por classes: $41 \%$ não atingiam os 500.000 réis patrimoniais, $60 \%$ não alcançavam um milhão e só $1,7 \%$ ultrapassava os 10 contos.

Surge também com nitidez outra diferença relativamente às de beneficência: o peso percentual dos seus bens móveis, que era de 13,3\%, enquanto nas de beneficência, excluída a Misericórdia de Coimbra, se ficava pelos

\footnotetext{
${ }^{39}$ Lopes, Maria Antónia - Pobreza, assistência e controlo social..., cit., p. 134-135.
} 
$2,8 \%$. Isto é, quanto mais pobres, maior era a representatividade das alfaias e mobiliário.

Embora só dez confrarias tivessem instalações próprias, pois as restantes alojavam-se nas igrejas matrizes ou noutros templos, os seus bens de raiz atingiam os $29 \%$, valor muito próximo do que era detido pelos institutos de beneficência, onde, sem a Misericórdia de Coimbra, equivalia a 30\%. E também os capitais emprestados (56\%), ainda que em menor proporção, constituíam a maior fatia do património das irmandades.

Quadro 8 - Estrutura patrimonial do total das instituições de piedade do distrito de Coimbra em 1876/78

\begin{tabular}{|c|c|c|c|}
\hline Tipo & Réis & $\begin{array}{c}\text { Com } \\
\text { ilícitos }\end{array}$ & $\begin{array}{l}\text { Bens } \\
\text { lícitos }\end{array}$ \\
\hline Capitais mutuados por escritura pública & 93.628 .878 & $34,43 \%$ & $44,42 \%$ \\
\hline $\begin{array}{l}\text { Bens imóveis a desamortizar (só } 114 \\
\text { os declaram) }\end{array}$ & 61.121 .059 & $22,48 \%$ & \\
\hline $\begin{array}{l}\text { Títulos de dívida pública recebidos pelos } \\
\text { bens desamortizados }\end{array}$ & 43.550 .000 & $16,02 \%$ & $20,66 \%$ \\
\hline Bens móveis & 36.034 .195 & $13,25 \%$ & $17,10 \%$ \\
\hline $\begin{array}{l}\text { Bens imóveis isentos da desamortização } \\
\text { Títulos de dívida pública de outras }\end{array}$ & 18.540 .260 & $6,82 \%$ & $8,80 \%$ \\
\hline proveniências & 15.630 .702 & $5,75 \%$ & $7,42 \%$ \\
\hline Dívidas activas & 3.352 .906 & $1,23 \%$ & $1,59 \%$ \\
\hline $\begin{array}{l}\text { Papéis de crédito de estabelecimentos } \\
\text { particulares }\end{array}$ & 44.044 & $0,02 \%$ & $0,02 \%$ \\
\hline Total do património detido & 271.902 .044 & $100,00 \%$ & \\
\hline Total do património lícito & 210.780 .985 & & $100,00 \%$ \\
\hline
\end{tabular}

O governador civil de 1872 calculava que os capitais das confrarias do distrito ultrapassavam os 600 contos de réis, sendo impossível saber com precisão quais os seus rendimentos enquanto não se ultimasse a venda dos bens imposta pela $1 \mathrm{li}^{40}$. Face aos valores apurados em 1876-78, esse cômputo parece, pois, muito exagerado.

${ }^{40}$ Osorio, Antonio Gouveia - Relatorio apresentado à Junta Geral do Districto de Coimbra na sessão ordinaria de 1872. Coimbra: Imprensa da Universidade, 1872, p. 10. 


\section{Receitas e despesas}

A fonte utilizada informa-nos também sobre as receitas e despesas do universo institucional arrolado, ainda que omissa para as misericórdias de Soure e do Botão e para 50 confrarias. No conjunto de 21 instituições de beneficência, a receita ultrapassava um pouco os 40 contos e a despesa os 37. Nestas, apresentavam saldos negativos o Asilo da Infância Desvalida, no valor de -471.655 réis, e as misericórdias da Figueira com -508.978, a de Buarcos com -116.860 e, o caso mais grave, a de Góis com -798.000.

No conjunto das instituições caritativas, o saldo entre dívidas activas e passivas era também a seu favor, no montante de 6 contos. Só a Misericórdia de Cantanhede vivia uma situação financeira calamitosa, pois apresentava-se endividada em 1.166.288 réis, tendo apenas 254.500 de receita. Mesmo que conseguisse cobrar todas as suas dívidas activas (em foros), o saldo era negativo em 877.393 réis.

As receitas médias, excluindo a Misericórdia de Coimbra, não atingiam um conto, ficando-se pelos 926 réis, mas, como seria de esperar face às fortunas já conhecidas, os rendimentos eram muito díspares.

Quadro 9 - Receitas das instituições de beneficência do distrito de Coimbra em 1876-1878

\begin{tabular}{|c|c|c|c|}
\hline Instituição & Receita & Instituição & Receita \\
\hline $\begin{array}{l}\text { Misericórdia } \\
\text { de Coimbra }\end{array}$ & 21.513 .458 & $\begin{array}{l}\text { Hospital da Sociedade } \\
\text { Humanitária Arganilense }\end{array}$ & 312.855 \\
\hline $\begin{array}{l}\text { Asilo de Mendicidade de } \\
\text { D. Pedro V } \\
\text { Misericórdia da }\end{array}$ & 4.345 .662 & Misericórdia de Buarcos & 305.080 \\
\hline Figueira da Foz & 2.670 .988 & Misericórdia de Arganil & 285.540 \\
\hline $\begin{array}{l}\text { Confraria de Campos } \\
\text { (Montemor) }\end{array}$ & 2.201 .420 & Misericórdia de Cantanhede & 254.500 \\
\hline Misericórdia de Pereira & 2.175 .040 & Misericórdia da Lousã & 234.415 \\
\hline $\begin{array}{l}\text { Misericórdia de Tentúgal } \\
\text { Asilo de Infância }\end{array}$ & 1.237 .435 & Misericórdia de Semide & 145.816 \\
\hline $\begin{array}{l}\text { Desvalida } \\
\text { Ordem Terceira de }\end{array}$ & 1.074 .870 & Misericórdia de Góis & 105.600 \\
\hline $\begin{array}{l}\text { Coimbra } \\
\text { Misericórdia de Vila }\end{array}$ & 881.555 & $\begin{array}{l}\text { Pampilhosa } \\
\text { Misericórdia de Vila Nova }\end{array}$ & 62.120 \\
\hline $\begin{array}{l}\text { Cova de Sub-Avô } \\
\text { Misericórdia de }\end{array}$ & 831.365 & de Anços & 37.210 \\
\hline Montemo & 510.000 & Misericórdia do Botão & ? \\
\hline Misericórdia de Galizes & 486.030 & Misericórdia de Soure & $?$ \\
\hline Misericórdia de Penela & 369.035 & Total & 40.039 .994 \\
\hline
\end{tabular}


Quadro 10 - Estrutura das receitas da Misericórdia de Coimbra e restantes instituições de beneficência do distrito em 1876-78

\begin{tabular}{lrrrr}
\hline \multirow{2}{*}{ Tipo } & \multicolumn{2}{c}{ Misericórdia de Coimbra } & \multicolumn{2}{c}{ Restantes $^{\mathbf{4 1}}$} \\
\cline { 2 - 5 } & \multicolumn{1}{c}{ Réis } & \% & \multicolumn{1}{c}{ Réis } & \multicolumn{1}{c}{$\%$} \\
\hline Juros de capitais mutuados & 11.312 .437 & 52,6 & 1.842 .042 & 9,9 \\
Juros de títulos de dívida pública & 4.812 .000 & 22,4 & 3.222 .920 & 17,4 \\
Cobrança de dívidas activas & 3.163 .905 & 14,7 & 1.806 .638 & 9,8 \\
Outras proveniências & 1.533 .241 & 7,1 & 3.475 .133 & 18,8 \\
Bens e direitos imóveis & 663.915 & 3,1 & 5.436 .042 & 29,3 \\
Legados e donativos para & & & & \\
constituir fundo & 27.960 & 0,1 & 1.531 .465 & 8,3 \\
Esmolas & - & 0,0 & 896.300 & 4,8 \\
Juros de papéis de crédito & - & 0,0 & 315.996 & 1,7 \\
\hline Total da Receita & 21.513 .458 & 100,0 & 18.526 .536 & 100,0 \\
\hline
\end{tabular}

A tipologia das receitas da Misericórdia de Coimbra era completamente distinta das demais. Aquela assentava nos juros, que constituíam $75 \%$ dos réditos; as outras sustentavam-se tanto de juros (29\%), como de rendimentos provenientes dos bens e direitos imóveis, que eram já todos ilegais mas representavam também 29\% das receitas. De notar, ainda, que a Misericórdia de Coimbra não auferia receitas de esmolas, o que nas outras tinha uma pequena expressão. Mais relevante, assinale-se a diferença percentual dos réditos provenientes de legados e donativos.

As instituições pias tinham, no seu conjunto, uma receita anual de 19,3 contos, sendo a despesa de 15,5 . O saldo, representando $20 \%$ da receita, era muito elevado, sem comparação com as de beneficência, onde atingia apenas 7,6\%. De facto, se as 148 confrarias para as quais possuímos dados tinham um rendimento superior ao de 20 instituições de beneficência (que totalizava 18,5 contos) ${ }^{42}$, as despesas destas ascendiam a 16,2 contos, superior, portanto, ao que as irmandades gastavam. Ora, se não gastavam, entesouravam.

${ }^{41}$ Com exclusão, por lacuna documental, das misericórdias de Soure e do Botão.

${ }^{42}$ Excluiu-se a Misericórdia de Coimbra por ser um caso especialíssimo no conjunto das instituições e as misericórdias de Soure e do Botão, cujas receitas e despesas não são fornecidas pela fonte utilizada. 
Apenas onze irmandades registavam saldos negativos. A situação mais grave era a do Santíssimo de Castelo Viegas (Coimbra), cujo deficit, no valor de 209.335 réis, correspondia a $513 \%$ da sua receita anual. As homónimas de Candosa (Tábua) e do Rabaçal (Penela) vinham a seguir, com saldos negativos que equivaliam a $183 \%$ e a $132 \%$ dos rendimentos. As confrarias do Santíssimo, no Paião (Figueira) e em Torre de Vilela (freg. Brasfemes, concelho de Coimbra), estavam mais desafogadas, com défices correspondentes a $68 \%$ e $44 \%$ das receitas. Nas restantes seis os saldos negativos escalonavam-se entre $0,5 \%$ e $8 \%$ dos rendimentos.

Era também muito elevado o saldo positivo das dívidas, ultrapassando os 8 contos $^{43}$. Estes números demonstram que as irmandades, no seu conjunto, não se encontravam endividadas, mas revelam também uma deficiente gestão, incapaz de resgatar os débitos. Repare-se que as dívidas activas equivaliam a $45 \%$ da receita, sendo de $25 \%$ nas instituições de beneficência. Tais resultados parecem justificar os governantes portugueses quando advogavam a fiscalização das contas das confrarias, que diziam mal administradas ou mesmo espoliadas pelos confrades, e a canalização das suas sobras para colmatar necessidades sociais.

E parecem também dar razão à opinião expressa desde há muito por alguns governadores do distrito de Coimbra. Declarara o de 1851: "As irmandades e confrarias no nosso districto achão-se no mesmo estado disgraçado de administração que as misericordias e os hospitaes. Desta maneira não vos surprehenda que os seus rendimentos sejam na maior parte consumidos inutilmente". Dezoito anos depois, escrevia o seu homólogo: "É ainda pouco regular o estado da administração das irmandades e confrarias do districto. (...). Se ha trinta annos se tivesse cuidado seriamente da administração d'estas instituições de piedade e de caridade, ter-se-iam obstado ás escandalosas delapidações que se têm dado e podíamos hoje dispor de recursos valiosos para organizar a beneficencia publica no districto" 44 .

${ }^{43}$ Só 11 confrarias estavam endividadas, mas apenas 4 não possuíam dívidas activas que cobrissem esses valores: a Confraria dos Santos Mártires de Marrocos, de Coimbra, e as do Santíssimo de Outil (Cantanhede), de Ceira (Coimbra) e de Reveles (Montemor).

${ }^{44}$ Cit. por Roque, João Lourenço - Classes populares no distrito de Coimbra..., cit., p. 686-687. 
Assim, no distrito de Coimbra dos anos 1876-1878 o conjunto das instituições pias e beneficentes auferia receitas no valor de 59 contos, despendendo 53. Estas somas superam bastante os cálculos efectuados uns anos antes. O governador civil de 1865 avaliava o total da receita em 36 contos e o de 1869 em 39 contos. Este último calculava que despendiam cerca de 45 contos, sendo 20 da Misericórdia de Coimbra ${ }^{45}$.

Anível individual, as confrarias eram instituições pobres. Considerando as que declaram as suas contas (75\%) em 1876-78, as suas receitas médias anuais não iam além dos 130.224 réis e as despesas eram apenas de 104.570 rs. Confrontem-se com as instituições de beneficência, cujos rendimentos médios auferidos, excluindo a Misericórdia de Coimbra, eram 7 vezes superiores, sendo as despesas 8 vezes mais elevadas.

Quadro 11 - Receitas e despesas das instituições de piedade do distrito de Coimbra em 1876-78. Distribuição por classes

\begin{tabular}{lcccc}
\hline \multicolumn{1}{c}{ Classes } & \multicolumn{2}{c}{ Receitas } & \multicolumn{2}{c}{ Despesas } \\
\hline \multicolumn{1}{c}{ Réis } & N $^{\text {os }}$ abs & \multicolumn{1}{c}{$\%$} & Nos abs. & \multicolumn{1}{c}{$\%$} \\
\hline$<50.000$ & 45 & $30,6 \%$ & 63 & $42,6 \%$ \\
$50.000-99.999$ & 46 & $31,3 \%$ & 41 & $27,7 \%$ \\
$100.000-199.999$ & 26 & $17,7 \%$ & 22 & $14,9 \%$ \\
$200.0000-499.999$ & 24 & $16,3 \%$ & 19 & $12,8 \%$ \\
$500.000-799.999$ & 4 & $2,7 \%$ & 3 & $2,0 \%$ \\
$>800.000$ & 2 & $1,4 \%$ & & $0,0 \%$ \\
\hline Total & 147 & $100,0 \%$ & 148 & $100,0 \%$ \\
\hline
\end{tabular}

Se com receitas médias anuais de 130.000 réis pouco poderiam fazer, que actividades conseguiriam desenvolver $70 \%$ das confrarias do distrito, com a contabilidade minimamente organizada e que nem cem mil réis despendiam?

${ }^{45}$ Roque, João Lourenço - Classes populares no distrito de Coimbra ..., cit., p. 686. 


\section{Actividades}

As irmandades declararam como seus objectivos: "culto religioso", "culto divino e bem espiritual dos irmãos", "esplendor do culto e sufrágio pelos irmãos falecidos", "sufragar e acompanhar os irmãos à sepultura", "honra e glória de Deus" ou "honra e glória de Nossa Senhora". Todavia, em 28 delas (14\%) mencionava-se a beneficência através de uma destas fórmulas: "culto divino e beneficência", "piedade e beneficência", "hospitalidade aos pobres e culto divino", "exaltação do culto divino, mútuo socorro aos confrades e instrução primária da freguesia", "reforçar a crença ao dogma da Imaculada Conceição de Nossa Senhora, subsidiar o ensino primário da freguesia e praticar actos de beneficência", "culto divino, sufrágios e socorros aos pobres", "obras de caridade", "beneficencia".

Três $(1,5 \%)$ afirmavam subsidiar o ensino primário: a Irmandade da Senhora da Conceição da Ponte, em Coimbra, a Irmandade do Santíssimo e Senhora do Rosário, em Foz de Arouce (Lousã), e a Irmandade do Santíssimo e Senhora do Rosário, no Espinhal (Penela). Só esta última vivia com desafogo, declarando a receita de 638.650 e a despesa de 466.300 . As outras duas gastaram num ano 79.090 e 69.445 réis. Mas também a Irmandade do Santíssimo, de Figueiró do Campo (Soure), contribuiu para a instrução primária: "posteriormente a este anno [1860] só se fez a despeza extraordinaria com a casa da eschola e moveis, que a confraria prestou, competentemente authorisada".

As confrarias que declararam praticar a beneficência ou a caridade fá-lo-iam, de facto? Repare-se no que se entende por caridade na Irmandade das Chagas de Santa Maria de Arrifana (Poiares): "Seus fins: É a caridade. Os fins da irmandade das Chagas são acompanhar gratuitamente os seus socios à ultima morada e os que não são sócios acompanham-nos mediante uma pequena grateficação e tem obrigação de mandar deser pela alma de cada um socio que morrer 45 missas; mas sendo casado tem 30 e 15 por alma de sua mulher". Leia-se também o que o administrador do concelho afirma sobre a Irmandade do Santíssimo, de $\mathrm{St}^{\mathrm{o}}$ André de Poiares, cuja finalidade declarada é "a Beneficencia": "A corporação não tem contas approvadas, por que a sua escripturação não está regular; e isto provem de não ter 
ninguem, que gratuitamente queira servir-lhe de escrivão. [...] Poucas corporações com tão poucos rendimentos tem feito tanto como esta, e a prova são as obras da capella das Necessidades em que se tem gasto mais de quatro ou cinco mil crusados e que está por concluir por falta de meios".

Por outro lado, aquelas que asseguravam praticar a beneficência, apresentando valores de despesas anuais, raramente atingiam os 100.000 réis. A confraria de S. Pedro da Pena (povoação da freguesia de Portunhos), cujos propósitos eram a "hospitalidade aos pobres e culto divino", auferia réditos no valor de 35.269 réis e em todo um ano gastara 30.020 réis. A Irmandade da Senhora da Conceição, nas Alhadas, que se dedicava a "obras de caridade", tinha um rendimento anual de 4.700 réis, tendo despendido 4.000. A das Almas, de Ferreira, que se propunha "socorrer os irmãos pobres e sufragar as almas", apresentava receitas e despesas no valor de 59.600. Mas, esclarece o administrador do concelho da Figueira da Foz, "não tem esta irmandade fundos nem rendimentos certos, vive de esmolas, que certos empregados solicitam dos confrades e mais devotos e é com ellas que occorrem à satisfação das suas obrigações".

Cinco confrarias com despesas anuais situadas entre 101.000-300.000 réis declararam também socorrer temporalmente os irmãos. Ultrapassavam ligeiramente esta mediocridade apenas duas agremiações, a já referida Irmandade do Santíssimo e Senhora do Rosário, do Espinhal, com receita de 638.650 réis e despesa de 466.300, cuja dupla invocação indicia resultar da anexação de duas irmandades; e a Ordem Terceira da Penitência, da Figueira da Foz, que afirmava dedicar-se ao "culto divino e esmolas a irmãos pobres" e auferia rendimentos no valor de 767.000 réis, tendo gasto 467.135. Contudo, como foi dito, canalizava para esmolas apenas uma pequena parte dos seus gastos. Não foi por acaso que o administrador do concelho a classificou como instituição de piedade.

Assim sendo, tenho poucas dúvidas de que a acção assistencial da maioria das irmandades, mesmo que reservada aos irmãos, era quase nula. Acima de tudo, dedicar-se-iam ao sufrágio das almas dos irmãos defuntos, cujos corpos acompanhavam à sepultura, e à celebração anual do seu santo patrono. Algumas nem isso praticavam. Eis o que revela o administrador do concelho de Tábua sobre a Irmandade da Senhora do Loreto, em Oliveirinha: "Esta irmandade em toda a sua gerencia tem sido um cahos; não tem livros 
de contas, nem mandam diser missas pelas almas dos irmãos falecidos; não pagam annuaes nem multas; não tem sido mais por assim diser uma reunião d'endeviduos, que combinaram entre si levarem qualquer d'elles fallecido á sepultura, sem quererem outro onus". O único rendimento que a Irmandade tinha era um foro de 3.000 réis, "não tendo escriptura nem outro decumento comprovativo, só apenas a posse de receber todos os annos aquella quantia". Funcionava, pois, nesta, como sem dúvida em muitas outras, a entreajuda de índole voluntária e particular potenciada pela pertença a um grupo ainda mais restrito do que o da comunidade da freguesia.

$\mathrm{O}$ inquérito de 1876 fornece dados que permitem perceber a estrutura das despesas das instituições beneficentes. Com elas desvendam-se as suas actividades.

Quadro 12 - Estrutura das despesas das instituições de beneficência do distrito de Coimbra $(1876-78)$

\begin{tabular}{lrrrr}
\hline \multirow{2}{*}{\multicolumn{1}{c}{ Rubrica }} & \multicolumn{2}{c}{$\begin{array}{c}c \\
\text { Misericórdia }\end{array}$} & \multicolumn{2}{c}{ Restantes $^{46}$} \\
\cline { 2 - 5 } & \multicolumn{1}{c}{ Réis } & \multicolumn{1}{c}{$\%$} & \multicolumn{1}{c}{ Réis } & \multicolumn{1}{c}{$\%$} \\
\hline Beneficência & 13.300 .358 & 63,9 & 7.008 .646 & 43,3 \\
Diversos & 1.986 .877 & 9,5 & 4.633 .807 & 28,6 \\
Manutenção de edifícios & 1.690 .774 & 8,1 & 1.996 .887 & 12,3 \\
Culto & 1.836 .120 & 8,8 & 1.850 .450 & 11,4 \\
Ordenados de funcionários & 1.416 .666 & 6,8 & 328.650 & 2,0 \\
Instrução & 576.327 & 2,8 & 381.890 & 2,4 \\
Total da Despesa & 20.807 .122 & 100,0 & 16.200 .330 & 100,0 \\
\hline
\end{tabular}

As instruções do inquérito esclareciam que à beneficência correspondiam "esmolas, alimentação, medicamentos, vestuario, roupas de cama dos recolhidos, e os ordenados dos medicos, enfermeiros e outros empregados especiaes"; que o culto incluía "os vencimentos dos respectivos ministros"; e que a instrução englobava "os gastos com livros e utensilios para o ensino e os ordenados dos professores e ajudantes".

\footnotetext{
${ }^{46}$ Com exclusão, por lacuna documental, das misericórdias de Soure e do Botão.
} 
Como se vê de imediato, a Misericórdia de Coimbra canalizava para a assistência e ensino aos pobres ${ }^{47}$ mais de $2 / 3$ das suas despesas. Assim o fazia pelo menos há um século, não se deixando enredar em dispendiosas manifestações de culto. De facto, em 1772-1779, 63\% das despesas da Santa Casa foram aplicadas na assistência aos pobres, a administração absorveu $7 \%$, as tenças $6 \%$ e o culto $24 \%$. Depois, a diminuição das despesas cultuais prosseguiu gradual e ininterruptamente: 19\% em 1780$-1800,13 \%$ em 1804-1830, 10\% em 1831-185048 e 9\% agora, em 1876/78. Não houve, pois, qualquer laicização das actividades da Misericórdia de Coimbra por imposição dos governos liberais. A paulatina menorização das práticas devocionais correspondeu à vontade dos seus dirigentes. E, apesar de algumas oscilações provocadas pelo crescimento das despesas administrativas, a beneficência ganhava cada vez mais relevo na acção desta Santa Casa: no mínimo 61\% em 1780-1800, 68\% em 1804-1830, 65\% em $1831-1850^{49}$ e $67 \%$ em $1876 / 78$.

De outra forma procediam as restantes instituições caritativas, cujas despesas médias anuais eram de 810.017 réis, mas nem metade destinavam à beneficência. Situação que os governantes e tantos outros observadores não podiam deixar de deplorar, pois tais instituições eram, ou deveriam ser, os esteios da política social do Estado liberal português. De facto, como justificar tais prioridades nas misericórdias e outros organismos, todos eles definidos legalmente como instituições beneficentes? A debilidade das receitas (que, porém, eram oito vezes superiores às das confrarias), a impreparação dos dirigentes e as rotinas instaladas ajudam a explicar a situação que, afinal, era comum a tantas outras misericórdias portuguesas. Contudo, ao dedicarem $46 \%$ das suas despesas à beneficência e ensino, a acção social desenvolvida no distrito de Coimbra por estas instituições seria superior ao que se verificava na generalidade das misericórdias do país ${ }^{50}$. Como é óbvio, essa média de $46 \%$ encobre fortes variações institucionais.

${ }^{47} \mathrm{O}$ ensino que a Misericórdia de Coimbra assegurava era ministrado nos seus Colégios dos Órfãos e das Órfãs.

${ }^{48}$ Lopes, Maria Antónia - Pobreza, assistência e controlo social..., cit., p. 136-137.

${ }^{49}$ IDEM, ibidem, loc. cit.

${ }^{50}$ Cf. Lopes, Maria Antónia e Parva, José Pedro - Introdução in Lopes, Maria Antónia e Paiva, José Pedro Paiva (dir.) - Portugaliae Monumenta Misericordiarum 8..., cit., p. 19. 
Quadro 13 - Peso percentual da acção social e do culto nas instituições de beneficência do distrito de Coimbra (1876-78)

\begin{tabular}{lrrr}
\hline \multicolumn{1}{c}{ Instituições } & Beneficência & Instrução & Culto \\
\hline Asilo de Infância Desvalida & $39,2 \%$ & $21,3 \%$ & $0,0 \%$ \\
Asilo de Mendicidade de D. Pedro V & $50,5 \%$ & $0,0 \%$ & $0,0 \%$ \\
Hospital da Confraria de Campos (Montemor) & $92,3 \%$ & $0,0 \%$ & $7,7 \%$ \\
Hospital da Sociedade Humanitária Arganilense & $100,0 \%$ & $0,0 \%$ & $0,0 \%$ \\
Misericórdia da Figueira da Foz & $40,6 \%$ & $0,0 \%$ & $0,0 \%$ \\
Misericórdia da Lousã & $2,9 \%$ & $0,0 \%$ & $77,6 \%$ \\
Misericórdia da Pampilhosa da Serra & $4,9 \%$ & $0,0 \%$ & $35,7 \%$ \\
Misericórdia de Arganil & $20,0 \%$ & $0,0 \%$ & $41,6 \%$ \\
Misericórdia de Buarcos & $12,3 \%$ & $3,6 \%$ & $37,2 \%$ \\
Misericórdia de Cantanhede & $48,3 \%$ & $4,3 \%$ & $13,6 \%$ \\
Misericórdia de Coimbra & $63,9 \%$ & $2,8 \%$ & $8,8 \%$ \\
Misericórdia de Galizes & $44,5 \%$ & $0,0 \%$ & $54,6 \%$ \\
Misericórdia de Góis & $1,0 \%$ & $0,0 \%$ & $10,3 \%$ \\
Misericórdia de Montemor-o-Velho & $31,2 \%$ & $0,0 \%$ & $58,9 \%$ \\
Misericórdia de Penela & $67,3 \%$ & $6,7 \%$ & $22,6 \%$ \\
Misericórdia de Pereira & $40,3 \%$ & $0,0 \%$ & $22,2 \%$ \\
Misericórdia de Semide & $56,8 \%$ & $0,0 \%$ & $22,9 \%$ \\
Misericórdia de Tentúgal & $29,6 \%$ & $0,6 \%$ & $11,0 \%$ \\
Misericórdia de Vila Cova de Sub-Avô & $16,4 \%$ & $1,5 \%$ & $52,2 \%$ \\
Misericórdia de Vila Nova de Anços & $42,9 \%$ & $0,0 \%$ & $10,2 \%$ \\
Ordem e Hospital da Ordem Terceira de Coimbra & $43,7 \%$ & $0,0 \%$ & $?$ \\
\hline
\end{tabular}

As instituições que haviam sido fundadas no regime liberal, respondendo a novas ideologias e necessidades, nada gastavam com o culto, como sucedia nos dois asilos de Coimbra, na Misericórdia da Figueira da Foz e no Hospital da Sociedade Humanitária Arganilense. Destaca-se esta última porque despendia com a assistência a totalidade dos seus gastos. Nas demais, apesar de nada se canalizar para actividades cultuais, outras despesas podiam absorver mais do que a beneficência directa, como sucedia na Misericórdia da Figueira, que incluiu em "gastos diversos" $59 \%$ da sua despesa. O Asilo da Infância Desvalida tinha as suas contas mais organizadas, declarando 23\% em "gastos diversos", mas o da Mendicidade englobou nesse item $47 \%$ dos dispêndios. É impossível perceber se se pretendia escamotear despesas não autorizadas nessa rubrica que nada esclarece. 
Só oito instituições reservavam à acção social a maior parte dos seus dispêndios: os hospitais de Arganil e de Montemor (Confraria de Campos), as misericórdias de Cantanhede, Coimbra, Penela e Semide e os dois asilos. Destaque-se o ensino, ainda que de escassa relevância, nas actividades das misericórdias de Cantanhede, Penela e Buarcos, uma novidade oitocentista na acção destas instituições, muito incentivada pelos governos centrais mas a que a maioria das Santas Casas se escusava. Repare-se também que a insignificância da actividade beneficente não resultava apenas da pobreza da instituição. A Misericórdia de Vila Nova de Anços era a que menos receitas auferia, a de Semide tinha rendimentos medíocres, situando-se no $4^{\circ}$ lugar no ranking das mais desabonadas e a de Cantanhede era a sexta mais pobre do distrito e a única endividada.

Contudo, mesmo nestas que reservavam à acção social fatia importante dos seus gastos, a desorganização podia ser flagrante. Eis o que escreve o administrador do concelho de Cantanhede: "A Misericórdia de Cantanhede bem como quase todas as Confrarias do concelho é um verdadeiro cahos". Os esclarecimentos sobre as receitas e despesas basearam-se nas contas prestadas pelo tesoureiro da Santa Casa perante a Mesa e outras informações colhidas aqui e ali em uma "immensidade de papeis avulsos, que constituem a escripturação da mesma Santa Caza". A despesa efectuada com instrução primária era uma gratificação que a Santa Casa costumava dar anualmente à professora da vila. Apurou-se também que a Misericórdia devia aos Hospitais da Universidade de Coimbra 832.208 réis e ao Hospital de S. José de Lisboa 334.080 pelo tratamento de doentes do concelho. Mais grave ainda, quanto à organização do seu arquivo corrente, é o caso da Misericórdia de Soure, o que impossibilitou o apuramento das suas receitas e despesas.

$\mathrm{O}$ extremo do incumprimento no que toca à protecção social encontra-se na Santa Casa de Góis, seguida de perto pelas misericórdias da Lousã e da Pampilhosa da Serra, esta última economicamente muito frágil. A primeira encaminhou $89 \%$ dos seus gastos para a reedificação da capela (e por essa razão é a que detém o maior défice) e a da Pampilhosa 49\% em "gastos diversos". Quanto à Misericórdia da Lousã, comportava-se como se fosse uma agremiação devocional. É a que apresenta maior diferença percentual entre os gastos de culto e assistência. Não obstante já estar na posse do hospital da vila, este, como esclarece o administrador, 
"foi construido por meio de subscripção e tem a deneminação do Hospital de S. João. Foi entregue à Santa Caza da Mizericordia para o administrar; mas como este estabelecimento não tem rendimentos para o seu custeio, não lhe tem dado a applicação para que foi feito" ${ }^{51}$. Embora com menor gravidade, as misericórdias de Vila Cova de Sub-Avô, Montemor-o-Velho, Arganil e Buarcos patenteavam também estruturas de despesas pouco consentâneas com a sua natureza institucional. Na Misericórdia de Arganil, que não tinha hospital, a verba de 32.220 réis gasta em actos de beneficência consistiu "em uma esmola annual, que se dá em quinta feira sancta, distribuindo pelos pobres da freguesia 2 alqueires de milho cosido e em outras esmolas em dinheiro aos pobres necessitados, que recorrem a este estabelecimento, não podendo designar-se o numero dos seccorridos". Não admira, pois, que os arganilenses tivessem tomado a iniciativa de fundar um hospital. É que também a Misericórdia vizinha de Vila Cova de Sub-Avô não o possuía, embora prestasse assistência médica domiciliária.

No distrito de Coimbra, 67\% das misericórdias não possuíam hospitais, a saber: as de Arganil, Botão, Buarcos ${ }^{52}$, Cantanhede, Coimbra ${ }^{53}$, Galizes, Góis, Montemor-o-Velho, Pampilhosa da Serra, Pereira, Vila Cova de Sub-Avô e Vila Nova de Anços. As misericórdias da Lousã e de Semide conservavam hospitais, mas encontravam-se inactivos por alegada incapacidade financeira. Assim, e apesar dos importantes Hospitais da Universidade - cuja dimensão dos socorros prestados suplantava todos os outros - a rede hospitalar pública do distrito de Coimbra na década de 1870 era frágil, assentando apenas em 7 estabelecimentos, 57\% deles geridos pelas

${ }^{51}$ Sobre o processo de criação deste hospital, ver documento no 243 em LoPEs, Maria Antónia e PAIVA, José Pedro (dir.) - Portugaliae Monumenta Misericordiarum 8. Tradição e modernidade..., cit. O hospital só começaria a funcionar em 1888 (Lemos, Eugénio de $-A$ Santa Casa da Misericórdia da vila da Lousã: resenha histórica. Lousã: Tip. Lousanense, 1966, p. 53-57).

${ }^{52}$ A Misericórdia de Buarcos tinha um pequeno albergue que também servia de hospital (cf. CASCÃo, Rui - Figueira da Foz e Buarcos..., cit., p. 489), mas segundos as informação de 1876 apenas albergava os que iam a banhos ou passavam pela localidade com cartas de guia (sobre as cartas de guia ver LoPEs, Maria Antónia - Protecção social em Portugal..., cit., p. 59-60).

${ }^{53}$ Caso sui generis entre as grandes misericórdias do país, mas que só não actuava a nível hospitalar porque se localizava na cidade universitária, onde o seu hospital era simultaneamente civil e de ensino. 
misericórdias. Proporção esta que, embora carecendo ainda de dados absolutos, arrisco afirmar ser inferior à que se verificava a nível nacional.

\section{Conclusões}

Além dos Hospitais da Universidade e do Hospício dos Abandonados, o distrito de Coimbra da década de 1870 possuía nos seus 17 concelhos 23 instituições dedicadas à beneficência: dezoito misericórdias, dois hospitais não administrados por essas irmandades, a Ordem Terceira de Coimbra e os Asilos da Infância Desvalida e de Mendicidade, também na sede distrital. Esta rede beneficente era na sua quase totalidade uma herança de Antigo Regime, pois como inovações institucionais existiam apenas os Asilos de Infância Desvalida e de Mendicidade, além do Hospício dos Abandonados, este sob tutela directa da administração pública.

As misericórdias eram as instituições de assistência mais numerosas do nosso país, embora com fortes disparidades na sua distribuição territorial, o que também se verificava no distrito de Coimbra, onde estavam ausentes em cinco concelhos.

As confrarias do distrito abeiravam-se das duas centenas, já após um forte decréscimo do seu número, que se verificara entre 1840 e 1872, período em que foram suprimidas $42 \%$. Santíssimo Sacramento, Almas do Purgatório e Virgem Maria, cultos impulsionados pela Contra-Reforma católica, reuniam $74 \%$ destas agremiações. Nem outro panorama seria de esperar, pois não só esses cultos se tinham enraizado profundamente nas populações, como também $89 \%$ das instituições pias do distrito eram de fundação anterior a 1834. Eram ainda inexistentes as invocações do Coração de Jesus e Coração de Maria e só duas confrarias procuravam difundir o dogma da Imaculada Conceição, proclamado em 1854. Embora as confrarias fossem em número superior ao das freguesias do distrito, existiam 43 paróquias (23\%) que não possuíam qualquer instituição confraternal.

Os irmãos das misericórdias representavam uma escassa minoria da população masculina, inferior a $2 \%$, como as misericórdias sempre desejaram para manter intacto o seu prestígio e o distanciamento em relação às outras agremiações. Nas confrarias, o panorama muda radicalmente. Se o número 
destas instituições declinara acentuadamente, o dos seus membros crescera. A sociabilidade confraternal do distrito envolvia $12 \%$ da população de ambos os sexos.

Em 1876 haviam passado dez anos sobre a legislação que decretara a desamortização dos bens das instituições pias e beneficentes. A fonte estudada permite concluir que, à excepção da Misericórdia de Coimbra - que alienara $72 \%$ dos bens visados pela desamortização -, a lei não fora cumprida, pois as restantes agremiações só haviam desamortizado cerca de um terço dos imóveis a isso obrigados.

O cadastro de 1876-78 revela que o conjunto das instituições de beneficência e de piedade do distrito de Coimbra reunia um valor patrimonial que, no mínimo, atingia os mil contos, pertencendo às primeiras $75 \%$ desse montante. A Misericórdia de Coimbra era mais rica do que todos os outros institutos assistenciais reunidos, abeirando-se a sua fortuna dos 459 contos de réis, e escalonando-se a riqueza dos restantes entre os 54,7 contos e os $100 \mathrm{mil}$ réis, incluindo os bens que deveriam ser alienados. Como estes equivaliam apenas a $27 \%$ do valor total do seu património e como a desamortização não implicou a expropriação dos bens, mas a aplicação do produto da venda em títulos de dívida pública, cuja propriedade e juros continuavam a pertencer às instituições, conclui-se que a lei da desamortização de 1866 esteve longe de provocar a total ruína destes estabelecimentos. Apesar do muito que faltava desamortizar, o grosso do património destas últimas instituições consistia já em capital investido em crédito oneroso (67\%). Na Misericórdia de Coimbra alcançava os $92 \%$.

Nas instituições pias o valor patrimonial médio era de 1,5 contos, montante 10 vezes inferior à riqueza média dos institutos de beneficência, mesmo excluindo a Santa Casa coimbrã. Embora só dez confrarias tivessem instalações próprias, os seus bens de raiz atingiam os $29 \%$, constituindo os capitais emprestados, também aqui, a maior fatia do património das irmandades $(56 \%)$.

Quanto às receitas e despesas, a Misericórdia de Coimbra auferia réditos anuais superiores a 21 contos, as restantes instituições assistenciais ficavam-se, em média, pelos 926 réis e as cultuais apenas pelos 130 réis. A tipologia das receitas da Santa Casa de Coimbra era completamente distinta das demais. Aquela assentava nos juros, que constituíam $75 \%$ dos 
réditos; as outras sustentavam-se tanto de juros (29\%), como de rendimentos provenientes dos bens e direitos imóveis, que eram já todos ilegais mas representavam também $29 \%$ das receitas.

No seu conjunto, as instituições cultuais não se encontravam endividadas, mas a sua gestão era deficiente, pois permaneciam por resgatar dívidas activas em montantes muito avultados. Facto que sugere não ser injustificada a opinião dos governantes portugueses quando advogavam a fiscalização das contas das confrarias e a canalização das suas sobras para colmatar necessidades sociais.

A grande maioria das irmandades declarou ter por finalidade a prática do culto e/ou o sufrágio das almas dos irmãos falecidos, mas 28 delas mencionaram também a beneficência. Todavia, analisando as suas contas e declarações, assim como as explicitações por parte dos administradores dos concelhos, restam poucas dúvidas de que a acção assistencial da maioria das irmandades, mesmo que reservada aos irmãos, era quase nula. Haveria, sim, entreajuda de índole voluntária.

A Santa Casa da Misericórdia de Coimbra canalizava para a assistência e ensino aos pobres mais de 2/3 das suas despesas. Assim o fazia pelo menos há um século: os gastos com o culto diminuíram gradual e ininterruptamente pelo menos desde 1780. Não houve, pois, qualquer lacização das actividades da Misericórdia de Coimbra por imposição dos governos liberais. De outra forma procediam as restantes instituições caritativas, que nem metade dos gastos aplicavam à beneficência. Situação que os governantes e tantos outros observadores não podiam deixar de deplorar. Contudo, ao dedicarem 46\% das suas despesas à beneficência e ensino - apesar de serem em minoria as que administravam hospitais - a sua acção social seria, talvez, superior ao que se verificava na generalidade das misericórdias do país.

Concluo, finalmente, frisando que o objectivo deste trabalho foi a análise exaustiva de uma fonte muito rica para o conhecimento do universo institucional de índole beneficente e cultual de um distrito português no século XIX. Sendo assim, a componente quantitativa é forçosa e assumidamente grande, o que, no meu entender, em nada o prejudica. Sem estas bases indispensáveis, não se pode avançar para uma panorâmica nacional e outras etapas interpretativas, que não podem ser nunca meras construções teóricas sem informação rigorosa. 
Mapa 1 - Distribuição concelhia das misericórdias do distrito de Coimbra (1876-78)

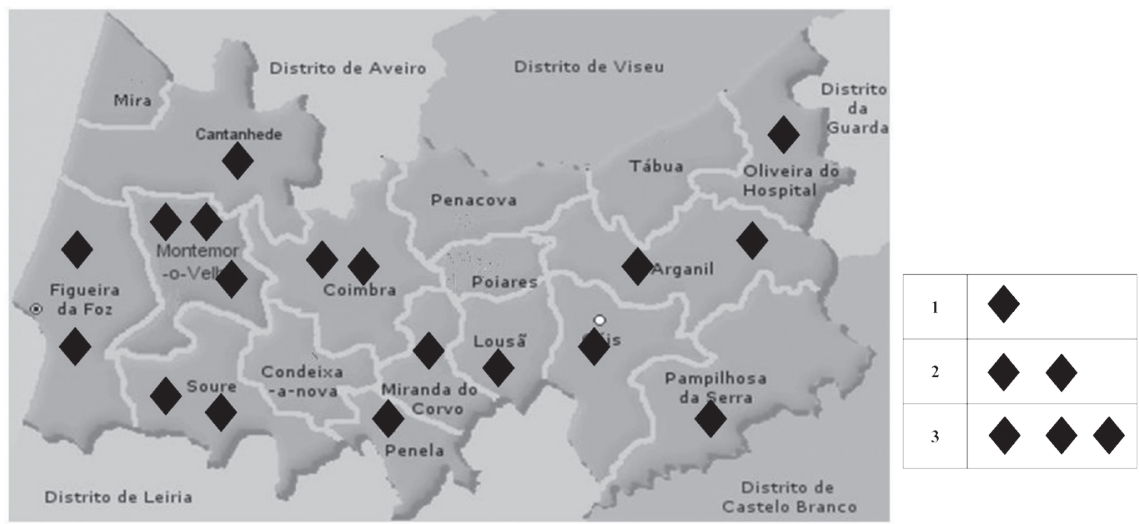

Mapa 2 - Distribuição concelhia das confrarias do distrito de Coimbra (1876-78)

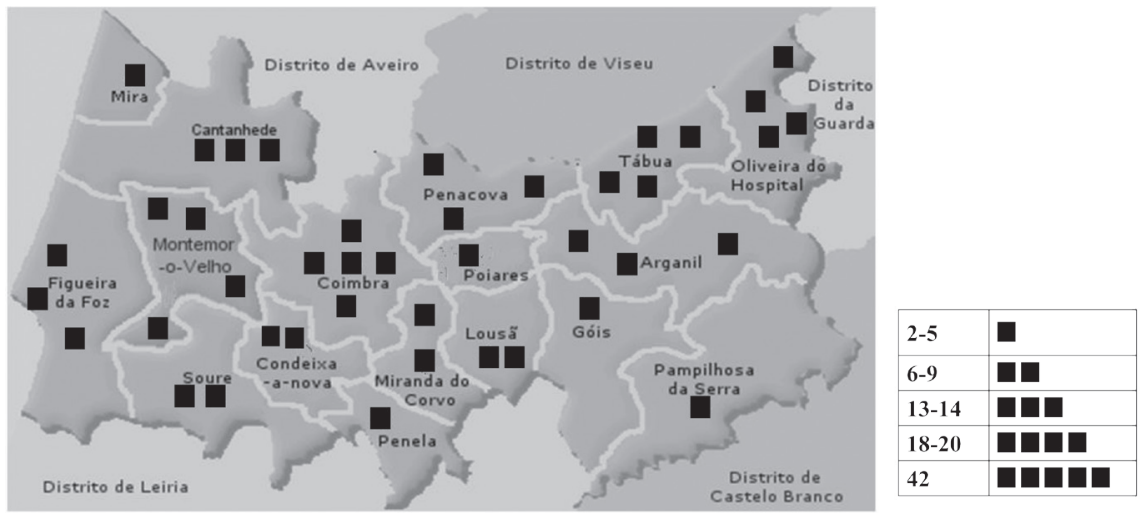

Mapa 3 - Peso demográfico dos confrades (misericórdias, confrarias e ordens terceiras) no distrito de Coimbra (1876-78)

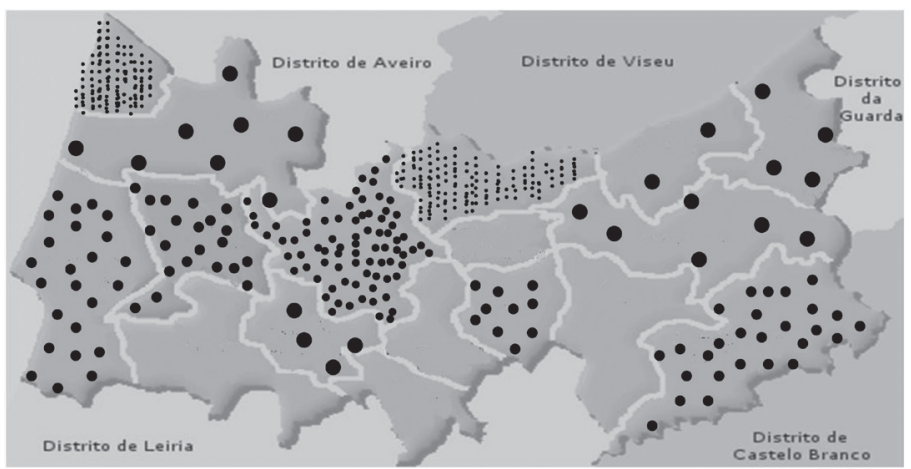

\begin{tabular}{|l|c|}
\hline $2 \%-6 \%$ & \\
\hline $7 \%-11 \%$ & \\
\hline $12 \%-16 \%$ & $\bullet$ \\
\hline $18 \%$ & $\cdots$ \\
\hline $27 \%$ & $\cdots$ \\
\hline
\end{tabular}

